\title{
Characterization and Pathogenicity of Colletotrichum Species on Philodendron tatei cv. Congo in Gansu Province, China
}

\author{
Longhai Xue, ${ }^{1,2}$ Yongwen Zhang, ${ }^{1}$ Tingyu Duan, ${ }^{1}$ Mengyuan Li, ${ }^{3}$ James F. White, ${ }^{4}$ Yong Liu, ${ }^{2, \dagger}$ and Chunjie Li ${ }^{1, \dagger}$ \\ ${ }^{1}$ State Key Laboratory of Grassland Agro-Ecosystems; Key Laboratory of Grassland Livestock Industry Innovation, Ministry of \\ Agriculture and Rural Affairs; Engineering Research Center of Grassland Industry, Ministry of Education; Gansu Tech Inno- \\ vation Center of Western China Grassland Industry; Center for Grassland Microbiome; College of Pastoral Agriculture Science \\ and Technology, Lanzhou University, Lanzhou 730020, China \\ ${ }^{2}$ Institute of Plant Protection, Sichuan Academy of Agricultural Sciences, Chengdu 610066, China \\ ${ }^{3}$ College of Management, Lanzhou University, Lanzhou 730020, China \\ ${ }^{4}$ Department of Plant Biology, Rutgers University, New Brunswick, NJ 08901-8520, U.S.A.
}

\begin{abstract}
In recent years in China, leaf spot caused by Colletotrichum species has been an emerging disease of Philodendron tatei cv. Congo. From 2016 to 2019 , typical symptoms, appearing as circular or ovoid, sunken, and brown lesions with a yellow halo, were commonly observed on $P$. tatei $\mathrm{cv}$. Congo in and around Lanzhou, Gansu Province, China. Conidiomata were often visible on infected leaf surfaces. Leaf disease incidence was approximately 5 to $20 \%$. A total of 126 single-spored Colletotrichum isolates were obtained from leaf lesions. Multilocus phylogenetic relationships were analyzed based on seven genomic loci (ITS, ACT, GAPDH, HIS3, CAL, CHS1 , and TUB2) and the morphological characters of the isolates determined. These isolates were identified as three Colletotrichum species in this study. A further 93 isolates, accounting for $74 \%$ of all Colletotrichum isolates, were described as new species and named as Colletotrichum philodendricola sp. nov. after the host plant genus name, Philodendron; another two

species-C. orchidearum. Both novel species $C$. philodendricola and $C$. pseudoboninense belong to the $C$. boninense species complex. Pathogenicity tests by both spray and point inoculations confirmed that all three species could infect leaves of $P$. tatei $\mathrm{cv}$. Congo. For spray inoculation, the mean infection rate of leaves on the three species was only $4.7 \%$ ( 0 to $12 \%$ ), and the size on lesions was mostly 1 to $2 \mathrm{~mm}$ in length. For point inoculation, 30 days after nonwounding inoculation, the infection rate on leaves was 0 to $35 \%$; in wounding inoculation, the infection rate of leaves was 35 to $65 \%$; wounding in healthy leaves greatly enhanced the pathogenicity of these three species to $P$. tatei $\mathrm{cv}$. Congo; however, the sizes of lesions among the three species were not significantly different. To our knowledge, this is the first report of Colletotrichum species associated with anthracnose diseases on P. tatei cv. Congo. Results obtained in this study will assist the disease prevention and appropriate management strategies.
\end{abstract} isolates were named as $C$. pseudoboninense sp. nov. based on phylogenetic and morphological relativeness to $C$. boninense; the other 31 isolates, belonging to the $C$. orchidearum species complex, were identified as a known
Keywords: Philodendron tatei cv. Congo, new species of Colletotrichum, brown spot, identification
Philodendron tatei cv. Congo (or Philodendron 'Congo'), family Araceae, is a cultivar of $P$. tatei (Osiecki 2000). P. tatei is widely used as a pot plant in homes and offices and is famous for its long lifespan in China (Lin et al. 2012; Zhou et al. 2014). It can improve the air quality in buildings because of its capability to absorb various toxic gases, including $\mathrm{SO}_{2}, \mathrm{SO}_{3}$, NO, etc. (Chen et al. 2012). Broader scale cultivation of $P$. tate $i \mathrm{cv}$. Congo has increased the chance of leaf diseases in Philodendron fields in China. For example, a severe outbreak of a soft rot caused by Dickeya dieffenbachiae on $P$. 'Congo' has occurred in three areas of Philodendron fields (5 ha) in Guangzhou, China, from 2010 to 2011 (Lin et al. 2012). In October 2013, a leaf spot of $P$. tatei cv. Congo caused by Alternaria alternata was observed in a residential district of Luoyang, China (Zhou et al. 2014).

${ }^{\dagger}$ Corresponding authors: Y. Liu, liuyongdr@163.com; C. J. Li, chunjie@1zu.edu.cn.

Funding: This work was supported by China Agriculture Research System Green Manure (CARS-022), Program for Changjiang Scholars and Innovative Research Team in University of China (IRT17R50), Fundamental Research Funds for the Central Universities (LZUJBKY-2019-kb10), and the 111 project (B12002), USDA-NIFA Multistate Project (W4147) and the New Jersey Agricultural Experiment Station.

The author(s) declare no conflict of interest.

Accepted for publication 15 April 2020.

This article is in the public domain and not copyrightable. It may be freely reprinted with customary crediting of the source. The American Phytopathological Society, 2020.
Anthracnose disease caused by Colletotrichum is one of the foremost diseases in crops and ornamental plants (Damm et al. 2012, 2019; Guarnaccia et al. 2016, 2017; Meneses et al. 2019). However, only a few studies of anthracnose on Philodendron have been conducted. Colletotrichum araceaerum, a synonym of C. orchidearum, was reported on P. selloum in China (Hou et al. 2016). Other Colletotrichum species associated with Philodendron were C. gloeosporioides (French 1989) and C. philodendri (Cho and Shin 2004). Previously, Colletotrichum species were only identified by using morphological and cultural characteristics (Smith and Black 1990; Tai 1979), whereas many studies demonstrated that morphological characters alone were misleading or unreliable for identification of Colletotrichum species because of their variations by different conditions (such as culture medium, temperature, host, strains, etc.) (Cavalcante et al. 2019; Damm et al. 2012). For example, the conidia of strain CBS 125377 (= CSSK4, C. hippeastri, China) on PDA were $29.2 \pm 5.5 \times 8.8 \pm 1.0, \mathrm{~L} / \mathrm{W}=3.3$ (Yang et al. 2009); whenever cultured on Spezieller Nahrstoffarmer agar (SNA), conidia of CBS 125377 were $28.5 \pm 4.1 \times 6.8 \pm$ $0.6 \mu \mathrm{m}, \mathrm{L} / \mathrm{W}=4.2$, and another strain CBS 241.78 (C. hippeastri, Netherlands) has shorter and broader conidia $(24.4 \pm 7.3 \times 7.2 \pm$ $0.7 \mu \mathrm{m}, \mathrm{L} / \mathrm{W}=3.4$ ) (Damm et al. 2012). Currently, including multigene phylogenetic analyses along with morphological characterization has become a common approach to accurately identify Colletotrichum species (Damm et al. 2012, 2019; Wang et al. 2019). Hence, the aims of this paper were to: (i) accurately identify new Colletotrichum isolates recovered from Philodendron leaf lesions to species level using morphological and phylogenetic studies; and (ii) determine their pathogenicity to Philodendron plants using pathogenicity tests.

\section{Materials and Methods}

Collection and isolation. In 2016, a leaf spot disease of $P$. tatei $\mathrm{cv}$. Congo was first found by Li Mengyuan in a private residence, and 
then often observed in another location in Lanzhou, Gansu Province, China. In order to identify the pathogens causing leaf spot on $P$. tatei $\mathrm{cv}$. Congo, successive samplings were performed in 2016 and 2019. In total, 17 locations (11 private residences and six flower markets) were investigated in Lanzhou city. Symptoms of leaf spot and leaf morbidity were observed and recorded, and symptomatic samples were collected. Pieces (about $1 \times 0.5 \mathrm{~cm}^{2}$ ) of leaf tissues at the border of lesions were cut from these samples. Colletotrichum species were isolated from the leaf lesions as described by Xue et al. (2019). According to the procedure provided by Cai et al. (2009), single-spored cultures were obtained for each Colletotrichum isolate. Representative isolates were deposited at the Mycological Herbarium of Lanzhou University (MHLZU), China General
Microbiological Culture Collection Center (CGMCC), and Agricultural Culture Collection of China (ACCC), respectively.

Morphological and cultural characterization. Fresh mycelial plugs ( $6 \mathrm{~mm}$ diameter) cut from the colonies were maintained at $20^{\circ} \mathrm{C}$ for 5 days in the dark and transferred to fresh oatmeal agar (OA) and potato dextrose agar (PDA). The growth rates in various temperatures were measured as described by Xue et al. (2019). After 4 days, growth rates were measured (computing formula: growth rate $(\mathrm{mm})=($ colony diameter -6$) / 2)$. The colony characteristics on OA or PDA were recorded between 4 and 30 days. Appressoria were observed by using the slide culture technique described by Cai et al. (2009). Colony colors were noted according to Rayner (1970). Morphological characters of cultures incubated under UV light with a

Table 1. Collection details and GenBank accession numbers of Colletotrichum species included in this study

\begin{tabular}{|c|c|c|c|}
\hline Colletotrichum species & Strainy & Host & Locality \\
\hline \multicolumn{4}{|c|}{ The Colletotrichum boninense species complex (CBSC) } \\
\hline C. annellatum & CBS $129826^{*}$ & Hevea brasiliensis & Colombia \\
\hline C. beeveri & CBS $128527 *$ & Brachyglottis repanda & New Zealand \\
\hline \multirow[t]{4}{*}{ C. boninense } & CBS 112115 & Leucospermum sp. & Australia \\
\hline & CBS $123755^{*}$ & Crinum asiaticum var. sinicum & Japan \\
\hline & CBS 128506 & Solanum lycopersicum & New Zealand \\
\hline & CBS 128549 & Solanum betaceum & New Zealand \\
\hline C. brassicicola & CBS 101059* & Brassica oleracea var. gemmifera & New Zealand \\
\hline C. citricola & CBS $134228 *$ & Citrus unchiu & China \\
\hline C. colombiense & CBS 129818* & Passiflora edulis & Colombia \\
\hline \multirow[t]{2}{*}{ C. constrictum } & CBS 128503 & Solanum betaceum & New Zealand \\
\hline & CBS 128504* & Citrus limon & New Zealand \\
\hline \multirow[t]{2}{*}{ C. cymbidiicola } & IMI $347923 *$ & Cymbidium sp. & Australia \\
\hline & CBS 128543 & Cymbidium sp. & New Zealand \\
\hline C. dacrycarpi & CBS $130241 *$ & Dacrycarpus dacrydioides & New Zealand \\
\hline C. hippeastri & CBS $125376^{*}$ & Hippeastrum vittatum & China \\
\hline \multirow[t]{3}{*}{ C. karstii } & CBS 110779 & Eucalyptus grandis & South Africa \\
\hline & CBS 126532 & Citrus sp. & South Africa \\
\hline & CBS 128545 & Capsicum аппиит & New Zealand \\
\hline C. novae-zelandiae & CBS $128505^{*}$ & Capsicum anпиит & New Zealand \\
\hline \multirow[t]{2}{*}{ C. oncidii } & CBS 129828* & Oncidium sp. & Germany \\
\hline & CBS 130242 & Oncidium sp. & Germany \\
\hline C. parsonsiae & CBS $128525 *$ & Parsonsia capsularis & New Zealand \\
\hline C. petchii & CBS 125957 & Dracaena sp. & Netherlands \\
\hline \multirow[t]{4}{*}{ C. philodendricola sp. nov. } & LZJZ1*= CGMCC 3.19290, MHLZU 0312, ACCC 39680 & Philodendron tatei cv. Congo & China \\
\hline & CGMCC 3.19931 = LZJZ2 & P. tatei cv. Congo & China \\
\hline & LZJZ3 & P. tatei cv. Congo & China \\
\hline & LZJZ4 & P. tatei cv. Congo & China \\
\hline C. phyllanthi & CBS $175.67 *$ & Phyllanthus acidus & India \\
\hline \multirow[t]{2}{*}{ C. pseudoboninense sp. nov. } & LZJZ5*= CGMCC 3.19755, MHLZU 0364, ACCC 39681 & Philodendron tatei cv. Congo & China \\
\hline & CBS 123921 & Dendrobium kingianum & Japan \\
\hline C. torulosum & CBS 128544* & Solanum melongena & New Zealand \\
\hline C. gloeosporioides & CBS 112999* & Citrus sinensis & Italy \\
\hline \multicolumn{4}{|c|}{ The $C$. orchidearum species complex (COSC) } \\
\hline C. cattleyicola & CBS $170.49^{*}$ & Cattleya sp. & Belgium \\
\hline C. cliviicola & CBS $125375^{*}$ & Clivia miniata & China \\
\hline C. musicola & CBS $132885^{*}$ & Musa sp. & Mexico \\
\hline \multirow[t]{2}{*}{ C. orchidearum } & CBS $135131 *$ & Dendrobium nobile & Netherlands \\
\hline & UTFC 265 & Philodendron sp. & Iran \\
\hline Origin of $C$. aracearum & CGMCC $3.14982 *$ & Monstera deliciosa & China \\
\hline \multirow[t]{2}{*}{ Origin of $C$. aracearum } & CGMCC 3.14983 & P. selloum & China \\
\hline & LZJZ6 = CGMCC 3.19756, MHLZU 0364, ACCC 39682 & P. tatei cv. Congo & China \\
\hline C. piperis & IMI $71397 *$ & Piper nigrum & Malaysia \\
\hline C. plurivorum & CBS $125474 *$ & Coffea sp. & Vietnam \\
\hline \multirow[t]{2}{*}{ C. sojae } & ATCC $62257 *$ & Glycine $\max$ & U.S.A. \\
\hline & CBS 128510 & Medicago sativa & U.S.A. \\
\hline C. vittalense & CBS $181.82 *$ & Theobroma cacao & India \\
\hline C. brevisporum & CBS 129957 & Anthurium sp. & Thailand \\
\hline
\end{tabular}

y Ex-type cultures are emphasized with an asterisk (*). Strains in this study are shown in bold.

z ITS: internal transcribed spacers 1 and 2 together with 5.8S nrDNA; GAPDH: partial glyceraldehyde-3-phosphate dehydrogenase gene; $C H S 1$ : partial chitin synthase 1 gene; HIS3: histone3; ACT: partial actin gene; TUB2: partial beta-tubulin gene; $C A L$ : partial calmodulin gene. 


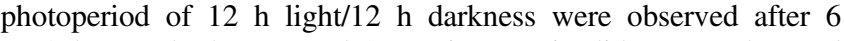
to14 days on both PDA and OA. Microscopic slides were observed with an LCD-Digital NSZ-808 (NOVEL) or a Nikon ECLIPSE $\mathrm{Ti}$ microscope. Thirty to 50 measurements were performed for each structure (conidia, appressoria, ascospores, asci, etc.). Duncan' $\mathrm{s}$ test $(P \leq 0.05)$ was used to compare relevant data by IBM SPSS Statistics v. 19 .

DNA extraction, PCR amplification, and DNA sequencing. DNA extractions and PCR amplifications were performed according to Xue et al. (2019). PCR products were sent to Sangon Biotech Co. Ltd. (Chengdu, China) for sequencing.

Phylogenetic analysis. Sequences used in this study are displayed in Table 1. Single sequences were first aligned using Clustal X function in MEGA v.6 (Tamura et al. 2013). Multiple loci were then combined with SequenceMatrix 1.8 (Vaidya et al. 2011). MEGA v.6 was used to determine the best DNA model for maximum likelihood (ML) analysis. Aligned sequences were analyzed using ML in MEGA v.6. The bootstrap analyses were based on 1,000 replicates. For Bayesian Inference (BI) analysis, the best-fit nucleotide substitution models of each gene were assessed by MrModeltest 2.3 software (Nylander 2004). Then BI were executed in MrBayes v. 3.2.6 (Ronquist et al. 2012). Analyses of MCMC chains based on the full dataset were run for two million generations and sampled every 100 generations. The first $25 \%$ of the generations were discarded as burnin. Finally, the tree was decorated in Microsoft PowerPoint 2016. The alignments and trees were deposited in TreeBASE (https://treebase.org/).

Table 1. (Continued from previous page)

\begin{tabular}{|c|c|c|c|c|c|c|c|}
\hline \multicolumn{7}{|c|}{ GenBank accessions $^{\mathbf{z}}$} & \multirow[b]{2}{*}{ References } \\
\hline ITS & GAPDH & CHS-1 & HIS3 & $A C T$ & $T U B 2$ & $C A L$ & \\
\hline \multicolumn{8}{|c|}{ The Colletotrichum boninense species complex (CBSC) } \\
\hline JQ005222 & JQ005309 & JQ005396 & JQ005483 & JQ005570 & JQ005656 & JQ005743 & Damm et al. 2012 \\
\hline JQ005171 & JQ005258 & JQ005345 & JQ005432 & JQ005519 & JQ005605 & JQ005692 & Damm et al. 2012 \\
\hline JQ005160 & JQ005247 & JQ005334 & JQ005421 & JQ005508 & JQ005594 & JQ005681 & Damm et al. 2012 \\
\hline JQ005153 & JQ005240 & JQ005327 & JQ005414 & JQ005501 & JQ005588 & JQ005674 & Damm et al. 2012 \\
\hline JQ005157 & JQ005244 & JQ005331 & JQ005418 & JQ005505 & JQ005591 & JQ005678 & Damm et al. 2012 \\
\hline JQ005156 & JQ005243 & JQ005330 & JQ005417 & JQ005504 & JQ005590 & JQ005677 & Damm et al. 2012 \\
\hline JQ005172 & JQ005259 & JQ005346 & JQ005433 & JQ005520 & JQ005606 & JQ005693 & Damm et al. 2012 \\
\hline KC293576 & KC293736 & KY856140 & KY856311 & KC293616 & KC293656 & KC293696 & Guarnaccia et al. 2017 \\
\hline JQ005174 & JQ005261 & JQ005348 & JQ005435 & JQ005522 & JQ005608 & JQ005695 & Damm et al. 2012 \\
\hline JQ005237 & JQ005324 & JQ005411 & JQ005498 & JQ005585 & JQ005671 & JQ005758 & Damm et al. 2012 \\
\hline JQ005238 & JQ005325 & JQ005412 & JQ005499 & JQ0055856 & JQ005672 & JQ005759 & Damm et al. 2012 \\
\hline JQ005166 & JQ005253 & JQ005340 & JQ005427 & JQ005514 & JQ005600 & JQ005687 & Damm et al. 2012 \\
\hline JQ005167 & JQ005254 & JQ005341 & JQ005428 & JQ005515 & JQ005601 & JQ005688 & Damm et al. 2012 \\
\hline JQ005236 & JQ005323 & JQ005410 & JQ005497 & JQ005584 & JQ005670 & JQ005757 & Damm et al. 2012 \\
\hline JQ005231 & JQ005318 & JQ005405 & JQ005492 & JQ005579 & JQ005665 & JQ005752 & Damm et al. 2012 \\
\hline JQ005198 & JQ005285 & JQ005372 & JQ005459 & JQ005546 & JQ005632 & JQ005719 & Damm et al. 2012 \\
\hline JQ005209 & JQ005296 & JQ005383 & JQ005470 & JQ005557 & JQ005643 & JQ005730 & Damm et al. 2012 \\
\hline JQ005207 & JQ005294 & JQ005381 & JQ005468 & JQ005555 & JQ005641 & JQ005728 & Damm et al. 2012 \\
\hline JQ005228 & JQ005315 & JQ005402 & JQ005489 & JQ005576 & JQ005662 & JQ005749 & Damm et al. 2012 \\
\hline JQ005169 & JQ005256 & JQ005343 & JQ005430 & JQ005517 & JQ005603 & JQ005690 & Damm et al. 2012 \\
\hline JQ005170 & JQ005257 & JQ005344 & JQ005431 & JQ005518 & JQ005604 & JQ005691 & Damm et al. 2012 \\
\hline JQ005233 & JQ005320 & JQ005407 & JQ005494 & JQ005581 & JQ005667 & JQ005754 & Damm et al. 2012 \\
\hline JQ005226 & JQ005313 & JQ005400 & JQ005487 & JQ005574 & JQ005660 & JQ005747 & Damm et al. 2012 \\
\hline MH105257 & MH105261 & MH105265 & MH105269 & MH105273 & MH105277 & MH105281 & This study \\
\hline MH105258 & MH105262 & MH105266 & MH105270 & MH105274 & MH105278 & MH105282 & This study \\
\hline MH105259 & MH105263 & MH105267 & MH105271 & MH105275 & MH105279 & MH105283 & This study \\
\hline MH105260 & MH105264 & MH105268 & MH105272 & MH105276 & MH105280 & MH105284 & This study \\
\hline JQ005221 & JQ005308 & JQ005395 & JQ005482 & JQ005569 & JQ005655 & JQ005742 & Damm et al. 2012 \\
\hline MK796540 & MK796573 & $\ldots$ & MK796580 & MK796547 & MK796554 & $\ldots$ & This study \\
\hline JQ005163 & JQ005250 & JQ005337 & JQ005424 & JQ005511 & JQ005597 & JQ005684 & Damm et al. 2012 \\
\hline JQ005164 & JQ005251 & JQ005338 & JQ005425 & JQ005512 & JQ005598 & JQ005685 & Damm et al. 2012 \\
\hline JQ005152 & JQ005239 & JQ005326 & JQ005413 & JQ005500 & JQ005587 & JQ005673 & Damm et al. 2012 \\
\hline \multicolumn{8}{|c|}{ The $C$. orchidearum species complex (COSC) } \\
\hline MG600758 & MG600819 & MG600866 & MG600905 & MG600963 & MG601025 & $\ldots$ & Damm et al. 2019 \\
\hline MG600733 & MG600795 & MG600850 & MG600892 & MG600939 & MG601000 & $\ldots$ & Damm et al. 2019 \\
\hline MG600736 & MG600798 & MG600853 & MG600895 & MG600942 & MG601003 & $\ldots$ & Damm et al. 2019 \\
\hline MG600738 & MG600800 & MG600855 & MG600897 & MG600944 & MG601005 & $\ldots$ & Damm et al. 2019 \\
\hline MG600740 & MG600802 & $\ldots$ & $\ldots$ & MG600946 & MG601007 & $\ldots$ & Damm et al. 2019 \\
\hline KX853166 & KX893585 & $\ldots$ & $\ldots$ & KX893577 & KX893581 & $\ldots$ & Hou et al. 2016 \\
\hline KX853167 & KX893586 & $\ldots$ & $\ldots$ & KX893578 & KX893582 & $\ldots$ & Hou et al. 2016 \\
\hline MK796541 & MK796574 & MK796567 & MK796581 & MK796548 & MK796555 & MK796561 & This study \\
\hline MG600760 & MG600820 & MG600867 & MG600906 & MG600964 & MG601027 & $\ldots$ & Damm et al. 2019 \\
\hline MG600718 & MG600781 & MG600841 & MG600887 & MG600925 & MG600985 & $\ldots$ & Damm et al. 2019 \\
\hline MG600749 & MG600810 & MG600860 & MG600899 & MG600954 & MG601016 & $\ldots$ & Damm et al. 2019 \\
\hline MG600751 & MG600812 & MG600862 & MG600901 & MG600956 & MG601018 & $\cdots$ & Damm et al. 2019 \\
\hline MG600734 & MG600796 & MG600851 & MG600893 & MG600940 & MG601001 & $\ldots$ & Damm et al. 2019 \\
\hline MG600762 & MG600822 & MG600869 & MG600908 & MG600966 & MG601029 & $\ldots$ & Damm et al. 2019 \\
\hline
\end{tabular}


Pathogenicity tests. Conidia were obtained by growing singlespored colonies on PDA or OA for 7 to 16 days as described. The conidial suspension was adjusted to a concentration of $1 \times 10^{8}$ conidia/ $\mathrm{ml}$ in sterile water. Qualitative filter papers (New Star No.102, Hangzhou Special Paper Industry, Hangzhou, China) were divided into 6-mm-diameter papers, and then dipped in conidial suspension, serving as the next pathogenicity tests. Pathogenicity tests were carried out on young and healthy plants (height: 20 to $30 \mathrm{~cm}$ ) of $P$. tatei cv. Congo.

Spray inoculation. For each isolate, five $P$. tatei $\mathrm{cv}$. Congo plants were spray-inoculated with conidial suspensions $\left(1 \times 10^{8}\right)$ by both wounding and nonwounding methods (Than et al. 2008). Control plants were spray-inoculated with sterile water. All plants were individually covered with transparent polyethylene bags for 10 days to maintain high relative humidity.

Point inoculation. For each isolate, 20 leaves of $P$. tatei cv. Congo plants were inoculated by both wounding and nonwounding methods. For nonwounding inoculation, 20 filter papers (6 mm diameter) immersed in conidial suspension were placed onto the upper surface of each leaf (the middle of one site per leaf along the longitudinal axis). For wounding inoculation, 20 leaves were first pinpricked, and then filter papers placed on the wound site (Scandiani et al. 2011). Control plants were inoculated with filter papers immersed in sterile water. Thereafter, all plants were spray-inoculated with sterile water, and individually covered with transparent polyethylene bags that had been moistened with sterile distilled water for 10 days (at the onset of symptoms). All plants were incubated in a greenhouse at 18 to $25^{\circ} \mathrm{C}$. Pathogenicity trials by both spray and localizing (filter paper) inoculations were performed three times as previously described. 30 days after inoculation, the morbidity of infected leaves was assessed and the length of lesions was measured to evaluate the virulence. Tukey's test $(P \leq 0.05)$ was used to analyze the data using IBM SPSS Statistics v.19. All fungal isolates included

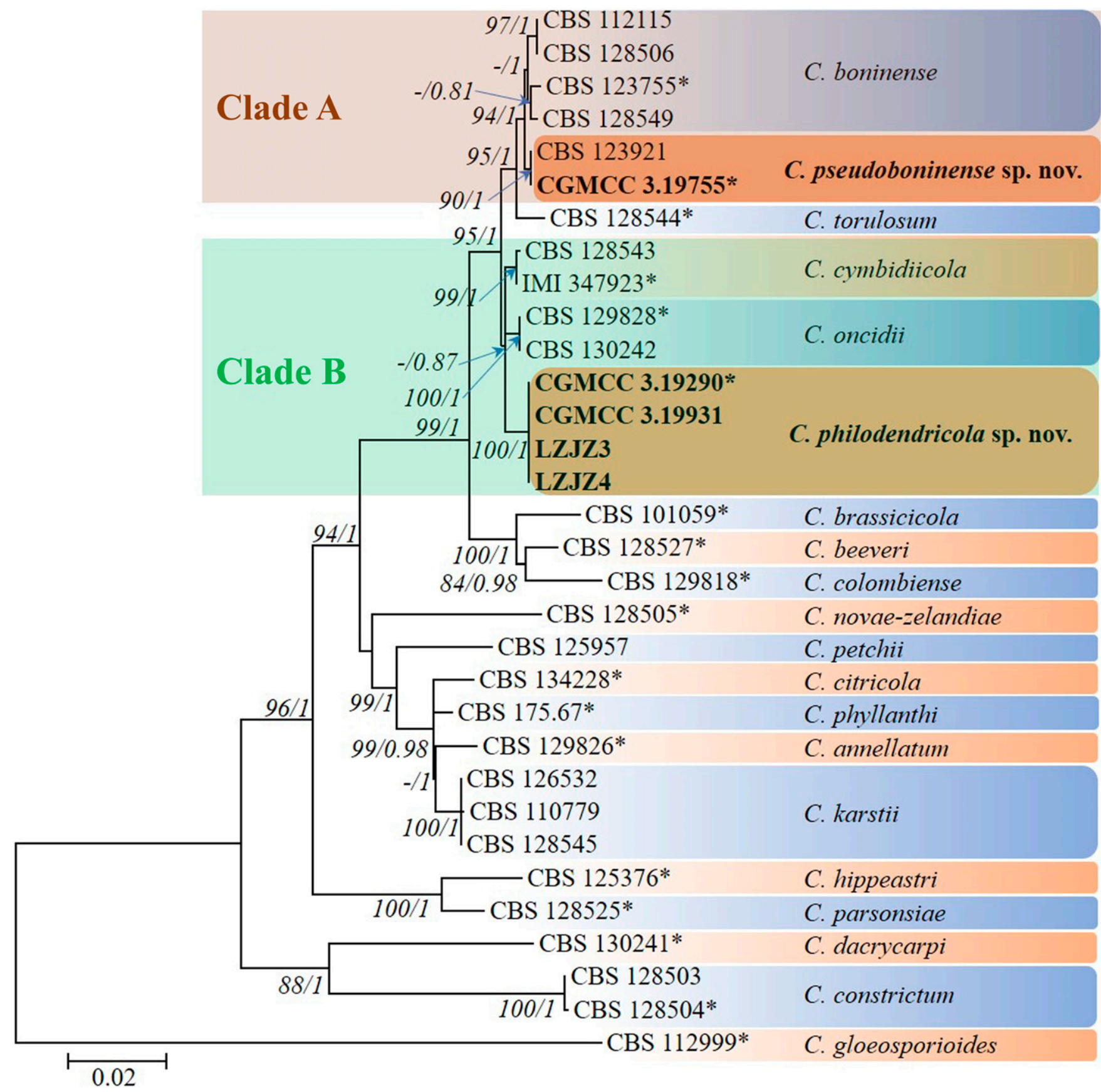

Fig. 1. Phylogram tree resulting from a maximum likelihood analysis based on the combined ITS, GAPDH, CHS-1, HIS3, ACT, TUB2, and CAL alignments of the Colletotrichum boninense species complex. Bootstrap support values (BS)/Bayesian posterior probability scores (PP) above 70\%/0.70 are shown at the nodes. Strains in this study are shown in bold. The tree was rooted to C. gloeosporioides (CBS 112999). Ex-epitype isolates are emphasized with an asterisk. TreeBASE: S25515. 

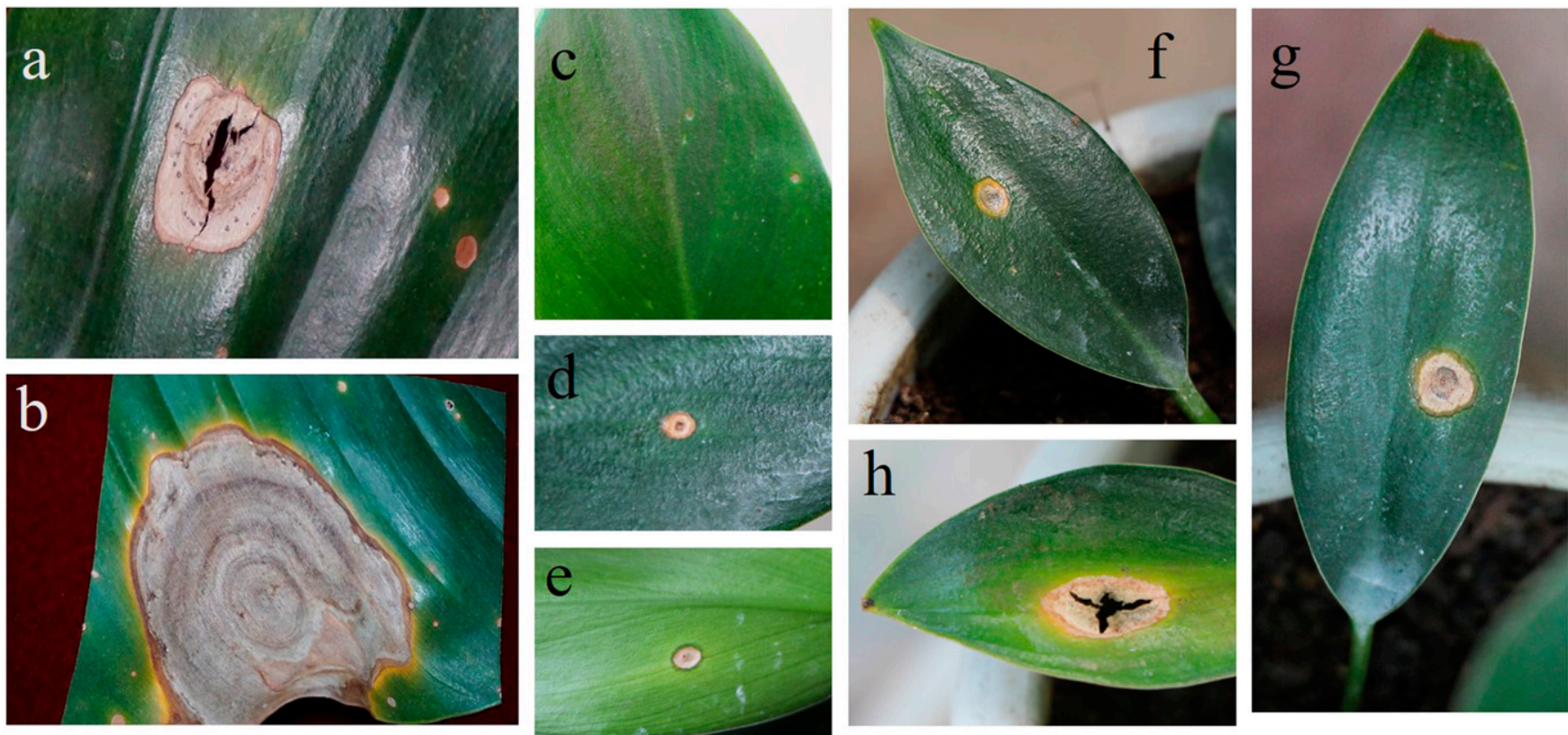

Fig. 2. Anthracnose of Philodendron tatei cv. Congo caused by Colletotrichum species. a-b, Leaf spots under natural conditions; c-e, symptoms on plants after spray inoculation with LZJZ1 (c, nonwounded plants; d-e, wounded plants); f-h, symptoms inoculated with filter papers on wounded leaves at 30 days (f, LZJZ5; g, LZJZ1; h, LZJZ6).

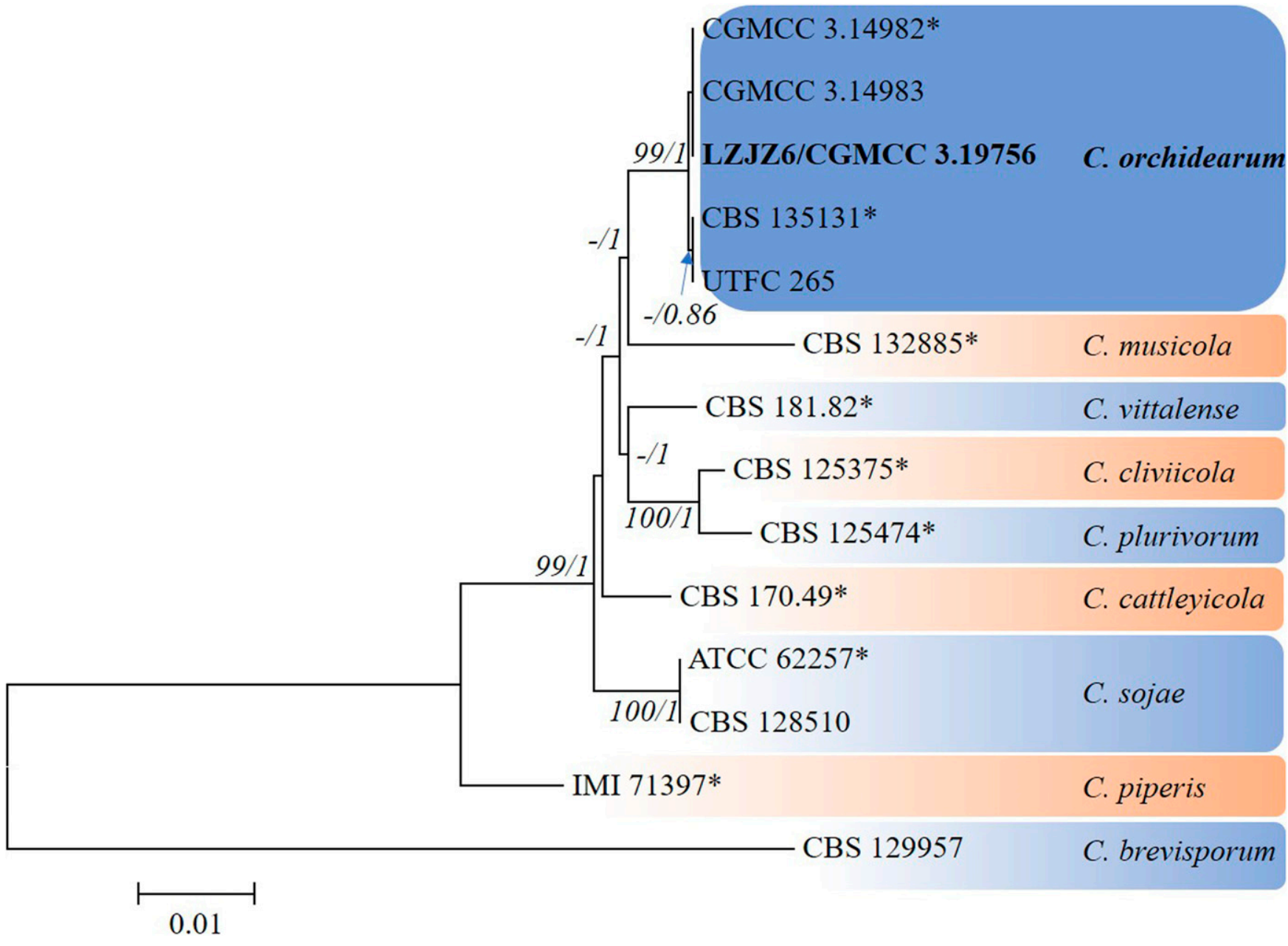

Fig. 3. Phylogram tree resulting from a maximum likelihood analysis based on the combined ITS, GAPDH, CHS-1, HIS3, ACT, and TUB2 alignments of the Colletotrichum orchidearum species complex. Bootstrap support values (BS)/Bayesian posterior probability scores (PP) above $70 \% / 0.70$ are shown at the nodes. Strains in this study are shown in bold. The tree was rooted to C. brevisporum (CBS 129957). Ex-epitype isolates are emphasized with an asterisk. TreeBASE: S25518. 
in the pathogenicity tests were reisolated from infected lesions to confirm their identity using both morphological and molecular approaches.

Genealogical concordance phylogenetic species recognition (GCPSR) analysis. In order to better reveal the novel species in this study, phylogenetically closely related isolates (Fig. 1, clade A and B) were selected for GCPSR analysis on a seven-locus concatenated dataset. A pairwise homoplasy index (PHI, or $\Phi_{\mathrm{w}}$ ) test was performed in SplitsTree4 (Huson and Bryant 2006) to determine the recombination level. If the PHI results were below a 0.05 level $\left(\Phi_{\mathrm{w}}<0.05\right)$, it indicated significant recombination present in the dataset (Bruen et al. 2006; Quaedvlieg et al. 2014). The splits graphs from the datasets based on both the LogDet transformation and splits decomposition options were used to reveal the relationships between these closely related species groups.

\section{Results}

Symptoms. During 2016 and 2019, anthracnose on leaves of $P$. tatei cv. Congo was frequently observed in and around Lanzhou, Gansu Province, China. Leaf disease incidence was approximately 5 to $20 \%$. The disease generally occurred at the tips and the margins

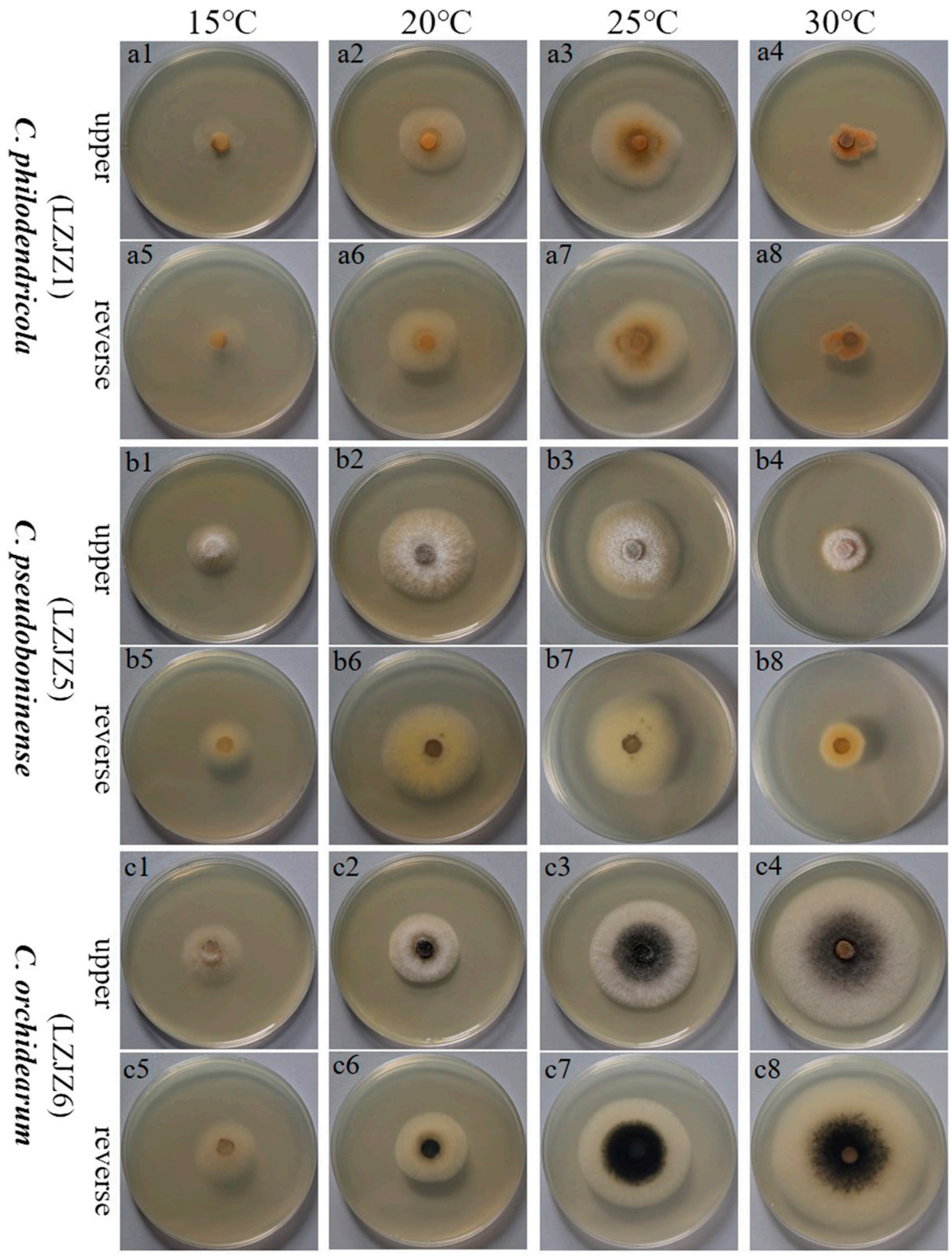

Fig. 4. Cultural traits of Colletotrichum species in this study. 
of older leaves. Early symptoms appeared as small, grayish white to yellow, circular or irregular, sunken spots (Fig. 2a). Leaf spots gradually expanded, leaving a dark-brown edge surrounded by an obvious yellow halo (Fig. 2b). Eventually, the infected sites of leaves formed a hole in the middle position of lesions. Conidiomata were often visible on the diseased leaf surfaces.

Colletotrichum species collection. In total, 126 single-spored $\mathrm{Col}$ letotrichum isolates were obtained from 78 symptomatic samples. Based on the high similarity of morphology on PDA as well as ITS, GAPDH, and TUB2 sequences, these cultures were preliminarily classified into three groups (i.e., Colletotrichum 1, Colletotrichum 2, and Colletotrichum 3). Colletotrichum 1 included 93 isolates that appeared as the most frequent species, including $74 \%$ of all isolates, followed by Colletotrichum 3 (31 isolates) and Colletotrichum 2 (two isolates). Six representative isolates from these three groups were subsequently selected for further phylogenetic studies (Table 1).

Phylogenetic analyses. Multiple loci (ITS, ACT, CAL, GAPDH, HIS3, CHS-1, and TUB2) of 32 isolates were selected from GenBank, including 26 isolates from the $C$. boninense species complex (CBSC), five representative Colletotrichum strains used in this study, and the type strain CBS 112999 (C. gloeosporioides), which was used as an outgroup. The dataset contained 2,714 characters including gaps after sequence alignment (546 for ITS; 278 for $A C T ; 442$ for $C A L$; 280 for $C H S-1$; 277 for GAPDH; 389 for HIS3; 502 for TUB2). The TN93+G model was selected to reconstruct the ML tree. For BI analysis, the corresponding models were selected by MrModeltest: $\mathrm{SYM}+\mathrm{I}+\mathrm{G}$ for ITS; GTR + I + G for HIS3; HKY +G for $A C T$ and $G A P D H$; GTR+G for $C A L$; and $\mathrm{K} 80+\mathrm{G}$ for $C H S 1$; and $\mathrm{HKY}+\mathrm{I}$ for TUB2. Only the ML tree is shown. The ML bootstrap support values (BS)/Bayesian posterior probability scores (PP) above $70 \% / 0.70$ are displayed at the tree nodes. The ML phylogenetic tree (Fig. 1; TreeBASE: S25515) showed that LZJZ1, LZJZ2, LZJZ3, and LZJZ4 isolates from Colletotrichum 1 group did not cluster well with any other Colletotrichum species, and were identified as C. philodendricola in this study; LZJZ5 from Colletotrichum 2, clustering with an unnamed isolate (CBS 123921) from the CBSC (Damm et al. 2012), was identified as C. pseudoboninense in this study. In order to better distinguish these two new species, the single-locus trees of each gene (ITS, ACT, CAL, GAPDH, HIS3, CHS-1, and TUB2) were also compared by both ML and BI analyses. In the CBSC analysis, the single loci GAPDH, HIS and CAL, separated C. pseudoboninense and $C$. philodendricola, respectively. In addition, $C$. philodendricola was separated also by TUB2 and $A C T$.

With the $C$. orchidearum species complex (COSC), a total of 2,243 characters (539 for ITS; 262 for ACT; 293 for $C H S-1 ; 242$ for $G A P D H$; 390 for HIS3; 517 for TUB2) including gaps were obtained from 14 Colletotrichum isolates (including 12 isolates from COSC, one representative Colletotrichum strain isolated from $P$. tatei cv. Congo, and a reference strain C. brevisporum (CBS 129957), which was used as an outgroup). For BI analysis, a GTR+I model was selected for ITS, HKY+I for $G A P D H$ and HIS3, K80+I for CHS-1, HKY for ACT, and $\mathrm{HKY}+\mathrm{G}$ for TUB2. A T $92+\mathrm{G}$ model was selected for ML analysis. The phylogram in Figure 3 (TreeBASE: S25518) showed that LZJZ6 from Colletotrichum 3 clustered well with four reported $C$. orchidearum isolates (Damm et al. 2019; Hou et al. 2016).

Morphological and cultural characteristics. Based on both analyses of multiple loci (Table 1) and morphological characterizations (Fig. 4; Table 2), the result of the final identification on these 126 cultures is consistent with those of the preliminary identification (only by morphology on PDA as well as ITS, GAPDH, and TUB2 sequences). Colletotrichum 3 isolates on PDA were cottony, dark greenish with white edges on the upper side, and black-green at the center on the reverse side (Fig. 5a and b). Colonies on OA were white to olivaceous on the upper side, reverse gray to gray-brown, and grew 16 to $17.3 \mathrm{~mm}$ in 4 days. Conidia on PDA were hyaline, aseptate, cylindrical, rounded at both ends, 14.6 to $21.1 \times 3.7$ to $5.8 \mu \mathrm{m}$ (mean \pm $\mathrm{SD}=17.4 \pm 1.4 \times 4.9 \pm 0.4, n=50, \mathrm{~L} / \mathrm{W}$ ratio $=3.6)$. Appressoria were dark brown, clavate, elliptic to irregular, 6.8 to $12.3 \times 3.7$ to $7.1 \mu \mathrm{m}$ (mean $\pm \mathrm{SD}=8.7 \pm 1.5 \times 6.1 \pm 1.0, n=14, \mathrm{~L} / \mathrm{W}$ ratio $=$ 1.4). The sexual morph of Colletotrichum 3 was produced on OA for 6 to 14 days. Ascomata were solitary, subglobose, dark brown to black, 74 to $363 \times 93$ to $474 \mu \mathrm{m}$. Asci were fasciculate, 8 -spored, brown, clavate, 61.3 to $101.5 \times 5.4$ to $13.7 \mu \mathrm{m}$ (Fig. $5 \mathrm{e}$ ). Ascospores were hyaline to yellow-brown, aseptate, allantoid, straight or slightly curved, sometimes with one or two acute ends, 10.1 to $23.7 \times 3.7$ to $6.6 \mu \mathrm{m}$ (mean $\pm \mathrm{SD}=17.7 \pm 3.3 \times 5.5 \pm 0.7, n=50, \mathrm{~L} / \mathrm{W}$ ratio $=3.2)$ (Fig. 5f to 1). The morphological features on PDA were generally similar to those of $C$. orchidearum (Ariyawansa et al. 2015; Yang et al. 2011). Phylogenetic analyses of multiple loci along with morphological characteristics confirmed that Colletotrichum 3 was $C$. orchidearum - a known species of the C. orchidearum species complex. The Colletotrichum 1 and Colletotrichum 2, both belonging to the $C$. boninense species complex, were named as $C$. philodendricola and $C$. pseudoboninense, respectively, based on their morphological and molecular characteristics in this study. The specific descriptions of the two novel species are as follows:

Colletotrichum philodendricola L. H. Xue \& C. J. Li, sp. nov.

MycoBank MB828468; Figure 6.

Etymology: Named after the host Philodendron tatei cv. Congo.

Morphological descriptions. Anamorph on PDA. Hyphae hyaline, aseptate, branched, 1.6 to $4.9 \mu \mathrm{m}$ diam. Conidiomata acervular, setae and conidiophores formed on pale to medium brown, thick-walled angular cell. Setae pale to dark brown, aseptate, sometimes including geniculate at the middle, 30 to $150 \mu \mathrm{m}$ long; base inflated or cylindrical, 3 to $6.5 \mu \mathrm{m}$ diam., tip acute. Conidiophores hyaline to gray, branched, to $102 \mu \mathrm{m}$ long. Conidia hyaline, aseptate, cylindrical, rounded or acute at ends, 9.3 to $18.1 \times 4.8$ to $6.5 \mu \mathrm{m}$ $($ mean $\pm \mathrm{SD}=14.0 \pm 1.6 \times 5.6 \pm 0.5, n=50, \mathrm{~L} / \mathrm{W}$ ratio $=2.5)$. Appressoria brown, ellipsoidal to irregular, or navicular, 6.0 to $17.9 \times$ 4.0 to $8.9 \mu \mathrm{m}($ mean $\pm \mathrm{SD}=10.0 \pm 2.1 \times 6.8 \pm 1.3, n=33$, $\mathrm{L} / \mathrm{W}$ ratio $=1.5)$.

Anamorph on OA. Hyphae hyaline, aseptate, branched, 1.5 to $6.5 \mu \mathrm{m}$ diam. Conidiomata acervular, setae and conidiophores formed from hyphae or on pale to medium brown, thick-walled angular cell 3.5 to $7 \mu \mathrm{m}$ diameter. Setae pale to dark brown, aseptate, straight to slightly curved, 43 to $295 \mu \mathrm{m}$ long, base inflated or cylindrical, tip acute, 3.2 to $6.3 \mu \mathrm{m}$ diameter, and the tip acute. Conidiophores unbranched or branched, hyaline to dark gray, to $85 \mu \mathrm{m}$ long. Conidia straight, aseptate, cylindrical to fusiform, 10.3 to $17.4 \times 4.1$ to $6.8 \mu \mathrm{m}($ mean $\pm \mathrm{SD}=13.8 \pm 1.3 \times 5.6 \pm 0.7, n=$ $50, \mathrm{~L} / \mathrm{W}$ ratio $=2.5$ ).

Colonies on PDA buff to honey, covered with orange, dark gray to black conidiomata, and white to gray aerial mycelium; orange conidial masses were visible; reverse pale salmon to honey. Colonies on OA usually white to pale honey-colored, visible with gray to dark conidiomata, and sparse white aerial mycelium; reverse gray, with dark spots because of conidiomata shining through, 19 to $21.3 \mathrm{~mm}$ in 7 days ( 30.5 to $31.5 \mathrm{~mm}$ in 10 days).

Specimen examined. Holotype: China. Gansu Province: Lanzhou, isolated from leaf lesions of $P$. tatei cv. Congo, Oct. 2016, Longhai Xue and Yongwen Zhang. Ex-type culture LZJZ1 = CGMCC $3.19290=$ MHLZU $0312=$ ACCC 39680 .

Notes: Phylogenetic analysis of multiple loci showed that $C$. philodendricola is a sister clade to $C$. cymbidiicola and $C$. oncidii, formed a single clade with high BS/PP values (100/1). BLAST analyses of each gene showed that the $A C T, C A L, G A P D H, H I S 3$, and TUB2 sequences of $C$. philodendricola differ from those of the two species (C. cymbidiicola and $C$. oncidii) by 4 to 5,1 to 3,7 to 9,1 to 2 , and 3 to 5 bp, respectively. Although the features of conidia are similar to those of both $C$. cymbidiicola and $C$. oncidii, $C$. philodendricola is different as setae are aseptate and 30 to $150 \mu \mathrm{m}$ shorter than both of the other species (C. cymbidiicola and C. oncidii) (75 to $180 / 210 \mu \mathrm{m}$, Table 2$)$, and the growth rate on OA (19 to $21.3 \mathrm{~mm}$ in 7 days) is significantly slower than the two species (C. cymbidiicola: 25 to $27.5 \mathrm{~mm}$ in 7 days; C. oncidii: 30 to $31.5 \mathrm{~mm}$ in 7 days). In addition, $C$. philodendricola was morphologically different with acute ends of its conidia.

Colletotrichum pseudoboninense L. H. Xue \& C. J. Li, sp. nov. MycoBank MB832454; Figure 7.

Etymology: Named after both the phylogenetic proximity and morphological similarity to $C$. boninense. 
Morphological descriptions. Teleomorph on OA (CGMCC 3.19755). Ascomata solitary, globose to ellipsoidal, dark brown to black, 55 to $137 \times 107$ to $253 \mu \mathrm{m}$. Asci fasciculate, 8 -spored, pale to dark brown, cylindrical to clavate, 29 to $64 \times 4.8$ to $12.7 \mu \mathrm{m}$ (mean $\pm \mathrm{SD}=45.5 \pm 9.4 \times 10.2 \pm 2.2, n=30$ ). Ascospores yellow brown, aseptate, straight to slightly curved, allantoid, round or acute at ends, 9.7 to $18.3 \times 3.8$ to $7.3 \mu \mathrm{m}($ mean $\pm \mathrm{SD}=15.7 \pm 1.8 \times 5.8 \pm 0.8, n=$ $50, \mathrm{~L} / \mathrm{W}$ ratio $=2.7)$.

Anamorph on PDA (CGMCC 3.19755). Hyphae hyaline, aseptate, branched, 1.4 to $5.6 \mu \mathrm{m}$ diam. Conidiomata acervular, setae and conidiophores formed on pale brown, roundish to angular cells. Setae rare, pale to dark brown, 0 to 4 septate, straight to curved, 70 to $170 \mu \mathrm{m}$ long, tip acute. Conidiophores hyaline to brown, branched or unbranched, to $30 \mu \mathrm{m}$ long. Conidia hyaline, aseptate, cylindrical to clavate, round at both ends, sometimes base with a hilum, 10 to $16.4 \times 4.8$ to $6.8 \mu \mathrm{m}($ mean $\pm \mathrm{SD}=13.2 \pm 1.5 \times 5.9 \pm 0.4, n=50$, $\mathrm{L} / \mathrm{W}=2.2$ ). Appressoria medium to dark brown, ovoid to irregular in shape, the margin entire to undulate, 6.6 to $11.0 \times 4.8$ to $8.4 \mu \mathrm{m}$ $($ mean $\pm \mathrm{SD}=8.3 \pm 1.3 \times 6.1 \pm 0.9, n=30, \mathrm{~L} / \mathrm{W}$ ratio $=1.4)$.

Colonies on PDA cottony, white to gray-brown, covered with white aerial mycelium, no conidial masses were visible; reverse white with brown on the center. Colonies on OA usually felty white to gray, covered with white aerial mycelium; reverse gray, with small black spots, 25.3 to $27.5 \mathrm{~mm}$ in 7 days.

Specimen examined. Holotype: China. Gansu Province: Lanzhou, isolated from leaf lesions of $P$. tatei $\mathrm{cv}$. Congo, Mar. 2019, Longhai Xue. Ex-type culture LZJZ5 = CGMCC $3.19755=$ MHLZU $0364=$ ACCC 39681. (culture CBS 123921 = MAFF 238642, isolate from Dendrobium kingianum. 1996, Kochi Pref.)

Notes: C. pseudoboninense was isolated from P. tatei $\mathrm{cv}$. Congo in China, and D. kingianum in Japan (Damm et al. 2012; Moriwaki et al.
2003). Multilocus phylogenetic analysis revealed that $C$. pseudoboninense is a sister clade to $C$. boninense, formed a single clade with high BS/PP values (90/1). BLAST analyses of each gene showed that the ACT, CAL, CHS-1, GAPDH, and HIS3 sequences of C. pseudoboninense were different from those of $C$. boninense by 1 to 5,8 to 13,1 to 2,7 to 8 , and 1 to 2 bp, respectively. The morphology of $C$. pseudoboninense is similar to that of $C$. boninense, but the asci of $C$. pseudoboninense are narrower (29 to $64 \times 4.8$ to $12.7 \mu \mathrm{m})$, and the length of setae is longer (70 to $170 \mu \mathrm{m}$ ) than those of $C$. boninense (CBS 123755 and CBS 123756) (asci: 45 to $60 \times 12.5$ to $17 \mu \mathrm{m}$; setae: 20 to 60 , or 30 to $70 \mu \mathrm{m}$ ). In addition, the ascospores on OA of $C$. pseudoboninense were aseptate when mature, which was clearly distinguishable from those of $C$. boninense (1 to 3 septate).

Effect of temperature on mycelial growth. For Colletotrichum 1 and 2 (i.e., C. philodendricola and C. pseudoboninense), the optimum growth temperature was $25^{\circ} \mathrm{C}$ (Table 3), while the optimum temperature for Colletotrichum 3 (i.e., C. orchidearum) was $30^{\circ} \mathrm{C}$ (Fig. 4). The three species isolated from $P$. tatei $\mathrm{cv}$. Congo were easily differentiated at 25,30 , and $35^{\circ} \mathrm{C}$, respectively $(P \leq 0.05)$; when cultured at these three temperatures, Colletotrichum 3 had the maximum growth rate of hyphae, followed by Colletotrichum 2 and Colletotrichum 1 (except that Colletotrichum 1 was higher than Colletotrichum 2 at $35^{\circ} \mathrm{C}$ ). No mycelial growth was observed at $0^{\circ} \mathrm{C}$ for any species. When compared at $10^{\circ} \mathrm{C}$, the growth rate of $\mathrm{Col}$ letotrichum 3 was significantly higher than Colletotrichum 1, but had not significant difference with Colletotrichum 2; Colletotrichum 3 was significantly higher than the other two groups at $15^{\circ} \mathrm{C}$; however, Colletotrichum 2 had a higher growth rate than Colletotrichum 1 and Colletotrichum 2 at $20^{\circ} \mathrm{C}$. In terms of temperature sensitivity, isolates of Colletotrichum 1 were sensitive to low temperatures $\left(10,15^{\circ} \mathrm{C}\right)$, and the growth rate was only $0.7 \mathrm{~mm} / 4$ days at $10^{\circ} \mathrm{C}$; isolates of

Table 2. Comparison of morphological and cultural characteristics of six close species from the Colletotrichum boninense species complex ${ }^{\mathrm{Z}}$

Colletotrichum species

C. boninense

C. pseudoboninense sp.

nov.

Origin of C. boninense

C. torulosum

C. cymbidiicola

C. oncidii

C. philodendricola sp. nov. CGMCC 3.19290* (= LZJZ1), LZJZ2, LZJZ3, LZJZ4
CBS 123921 (= MAFF 238642)

CBS 128544*, CBS 102667

IMI 347923*, CBS 128543, CBS 123757

OORC1

CBS 129828*, CBS 130242

CBS 123755* (= MAFF 305972), CBS 123756 (= MAFF

CGMCC 3.19755* (= LZJZ5)

IMI $34923 *$ CBS 128543, CBS 123757

CGMCC 3.19290* (= LZJZ1), LZJZ2, LZJZ3, LZJZ4
Colony on oatmeal agar

Felty white, covered with rosy buff or pale glaucous gray aerial mycelium, in the center pale luteous aerial mycelium

Felty white to gray, covered with pale to gray aerial mycelium, reverse with small black spots
Buff to honey, covered with orange to black conidiomata and
lacking aerial mycelium

Buff to straw, covered with white aerial mycelium or black conidiomata
White to pale honey-colored, visible with gray to dark
conidiomata, and sparse white aerial mycelium

(Continued on next page)

${ }^{\mathrm{z}}$ Strains in this study are shown in bold. Ellipsis (...) indicates absent. Ex-type cultures are emphasized with an asterisk (*). 
Colletotrichum 2 were more susceptible to high temperatures (only $0.8 \mathrm{~mm} / 4$ days at $35^{\circ} \mathrm{C}$ ) compared with the other two species; relatively speaking, isolates of Colletotrichum 3 were tolerant to high temperatures $\left(11.6 \mathrm{~mm} / 4\right.$ days at $\left.35^{\circ} \mathrm{C}\right)$.

Pathogenicity. Pathogenicity tested by both spray and point inoculations showed that all tested Colletotrichum isolates caused anthracnose lesions on leaves of $P$. tatei $\mathrm{cv}$. Congo inoculated by both wounding and nonwounding methods. No symptoms developed on the controls. Thirty days after inoculation, symptoms appeared as circular or ovoid, sunken, and brown lesions with a yellow halo, which were similar to the symptoms developed under natural conditions (Fig. 2). For spray inoculation, the proportions of leaves infected by the three species were 0 to $12 \%$ (mean $4.7 \%$ ); the lengths of leaf lesions on both nonwounded and wounded leaves were mostly 1 to $2 \mathrm{~mm}$ (e.g., Figure 2c, d, e). Because of the low rate and the small length of infected leaves, the differences between the three species were not compared in this study. For point inoculation, the mean infected rate of the three species was $35.8 \%$; when plants were inoculated without wounding, few leaves ( 0 to $35 \%$ ) developed lesions; with the wounding inoculation, the infection rate was $30 \%$ higher (Table 4). C. philodendricola, C. pseudoboninense, and $C$. orchidearum were reisolated from the infected leaves, and identified by morphological characters and sequence analyses to fulfill Koch's postulates.

GCPSR analysis. Clade A contains six isolates that had been identified as either belonging to closely related $C$. boninense (ex-type CBS 123755) or C. pseudoboninense (ex-type CGMCC 3.19755). Both species are phylogenetically distinct (Fig. 1) but are morphologically indistinguishable (Table 2). When applying the GCPSR concept to these isolates, we detect no significant recombination between these isolates $\left(\Phi_{\mathrm{w}}=1\right)$ (Fig. 8A), which is good support for the proposition that these isolates belong to two distinct taxa.

Clade B contains eight isolates that had been identified as $C$. oncidii and C. cymbidiicola (previously), and C. philodendricola (in this study) based on both morphology and multilocus DNA dataset. When applying the GCPSR concept to these isolates, we detected no significant recombination between these isolates $\left(\Phi_{\mathrm{w}}=1\right)$ (Fig. $8 \mathrm{~B})$. The split tree decomposition network of these multiple combinations was clearly detected within three separate groups. These results correspond to the phylogenetic tree (Fig. 1, clade B), which supports the proposition that $C$. oncidii and C. cymbidiicola, and C. philodendricola represent three different taxa, respectively.

\section{Discussion}

This study describes three pathogenic species of the genus Colletotrichum, of which $C$. orchidearum was a previously known species of COSC, and C. pseudoboninense and C. philodendricola were two novel species of CBSC. Species were identified and described using both multilocus phylogenetic analyses and morphological characteristics. To date, 23 species of CBSC have been clearly described (Damm et al. 2012; Guarnaccia et al. 2017; Hou et al 2016; Ma et al. 2018). None of these species have been previously reported on Philodendron.

It is almost impossible to accurately identify Colletotrichum species using morphological characteristics alone (Baroncelli et al. 2015; Cannon et al. 2000, 2012; Damm et al. 2009, 2012, 2019; Hou et al. 2016). Additionally, the ITS sequence region is too conserved to distinguish taxa in Colletotrichum (Begerow et al. 2010; Damm et al. 2012, 2019; Hou et al. 2016). For instance, C. boninense, $C$. oncidii, and C. cymbidiicola were not distinguished from each other by BLAST analysis of ITS sequence (Damm et al.

Table 2. (Continued from previous page)

\begin{tabular}{|c|c|c|c|c|}
\hline \multicolumn{2}{|c|}{ Anamorph } & \multicolumn{2}{|c|}{ Teleomorph } & \multirow[b]{2}{*}{ References } \\
\hline Setae & Conidia & Asci & Ascospores & \\
\hline $\begin{array}{l}\text { Rare, medium brown, } 1 \text { to } 2 \\
\text { septate, } 20 \text { to } 60 \text { or } 30 \text { to } 70 \mu \mathrm{m} \\
\text { long }\end{array}$ & $\begin{array}{l}\text { Cylindrical to clavate, base round } \\
\text { with a prominent hilum, } 9 \text { to } 16.5 \\
\times 4 \text { to } 6.5 \mu \mathrm{m} \text {, av. }=13.2 \times \\
5.8 \mu \mathrm{m}, \mathrm{L} / \mathrm{W}=2.3\end{array}$ & $\begin{array}{l}\text { Fascicle, cylindrical to clavate, } 8 \text { - } \\
\text { spored, } 45 \text { to } 60 \times 12.5 \text { to } 17 \mu \mathrm{m}\end{array}$ & $\begin{array}{l}1 \text { to } 3 \text {-septate, allantoid, } 12.5 \text { to } 18 \\
\times 4 \text { to } 6.5 \mu \mathrm{m}, \text { av. }=15.6 \times \\
5.4 \mu \mathrm{m}, \mathrm{L} / \mathrm{W}=2.9\end{array}$ & $\begin{array}{l}\text { Damm et al. } \\
2012\end{array}$ \\
\hline \multirow[t]{2}{*}{$\begin{array}{l}\text { Rare, pale to dark brown, } 0 \text { to } 4 \\
\text { septate, } 70 \text { to } 170 \mu \mathrm{m} \text { long }\end{array}$} & $\begin{array}{l}\text { Cylindrical to clavate, round at } \\
\text { both ends, sometimes base with } \\
\text { a hilum, } 10 \text { to } 16.4 \times 4.8 \text { to } \\
6.8 \mu \mathrm{m}, \text { av. }=13.2 \times 5.9 \mu \mathrm{m}, \\
\mathrm{L} / \mathrm{W}=2.2\end{array}$ & $\begin{array}{l}\text { Fascicle, cylindrical to clavate, } \\
8 \text {-spored, } 29 \text { to } 64 \times 4.8 \text { to } \\
12.7 \mu \mathrm{m}\end{array}$ & $\begin{array}{l}\text { Aseptate, allantoid, } 9.7 \text { to } 18.3 \times \\
3.8 \text { to } 7.3 \mu \mathrm{m}, \text { av. }=15.7 \times \\
5.8 \mu \mathrm{m}, \mathrm{L} / \mathrm{W}=2.7\end{array}$ & This study \\
\hline & $\begin{array}{l}\text { Cylindrical, obtuse at both ends, } \\
11.5 \text { to } 17 \times 4 \text { to } 7 \mu \mathrm{m}\end{array}$ & $\ldots$ & $\cdots$ & $\begin{array}{l}\text { Moriwaki } \\
\text { et al. } 2003\end{array}$ \\
\hline $\begin{array}{l}\text { Medium brown, } 0 \text { to } 2 \text { septate, } 20 \\
\text { to } 60 \mu \mathrm{m} \text { long }\end{array}$ & $\begin{array}{l}\text { Cylindrical, round at both ends, } \\
\text { with a prominent scar, } 13.5 \text { to } \\
17.5 \times 5 \text { to } 6.5 \mu \mathrm{m} \text {, av. }=15.5 \times \\
5.8 \mu \mathrm{m}, \mathrm{L} / \mathrm{W}=2.7(\mathrm{CBS} 102667 \text { : } \\
12 \text { to } 18 \times 5 \text { to } 6.5 \mu \mathrm{m}, \text { av. }=13.4 \\
\times 5.7 \mu \mathrm{m}, \mathrm{L} / \mathrm{W}=2.7)\end{array}$ & $\ldots$ & $\ldots$ & $\begin{array}{l}\text { Damm et al. } \\
2012\end{array}$ \\
\hline \multirow[t]{2}{*}{$\begin{array}{l}\text { Medium brown, } 1 \text { to } 4 \text { septate, } 75 \\
\text { to } 180 \mu \mathrm{m} \text { long }\end{array}$} & $\begin{array}{l}\text { Cylindrical, round at both ends, } \\
\text { with a prominent scar, } 11.5 \text { to } \\
16.5 \times 5 \text { to } 6.5 \mu \mathrm{m} \text {, av. }=14.6 \times \\
5.7 \mu \mathrm{m}, \mathrm{L} / \mathrm{W}=2.6\end{array}$ & $\begin{array}{l}\text { Cylindrical, } 8 \text {-spored, } 55 \text { to } 77 \times \\
11.5 \text { to } 13.5 \mu \mathrm{m}\end{array}$ & $\begin{array}{l}\text { Aseptate, cylindrical to fusiform, } \\
15 \text { to } 31 \times 5 \text { to } 7 \mu \mathrm{m} \text {, av. }=21.2 \times \\
5.5 \mu \mathrm{m}, \mathrm{L} / \mathrm{W}=3.9\end{array}$ & $\begin{array}{l}\text { Damm et al. } \\
2012\end{array}$ \\
\hline & $\begin{array}{l}\text { Cylindrical, round at both ends, } \\
\text { with a prominent scar, } 13.9 \text { to } \\
15.8 \times 5.6 \text { to } 5.9 \mu \mathrm{m} \text {, av. }=14.7 \times \\
5.8 \mu \mathrm{m}, \mathrm{L} / \mathrm{W}=2.53\end{array}$ & $\ldots$ & $\ldots$ & $\begin{array}{r}\text { Chowdappa } \\
\text { et al. } 2014\end{array}$ \\
\hline $\begin{array}{l}\text { Medium brown, } 2 \text { to } 5 \text { septate, } 75 \\
\text { to } 210 \mu \mathrm{m} \text { long }\end{array}$ & $\begin{array}{l}\text { Cylindrical, round at both ends, } \\
\text { with a prominent scar, } 14 \text { to } 17.5 \\
\times 5 \text { to } 6 \mu \mathrm{m}, \text { av. }=16.0 \times 5.4 \mu \mathrm{m} \text {, } \\
\mathrm{L} / \mathrm{W}=3.0\end{array}$ & $\ldots$ & $\ldots$ & $\begin{array}{l}\text { Damm et al. } \\
2012\end{array}$ \\
\hline $\begin{array}{l}\text { Pale to dark brown, aseptate, } 30 \\
\text { to } 150 \mu \mathrm{m} \text { long }\end{array}$ & $\begin{array}{l}\text { Cylindrical, round or acute at } \\
\text { ends, } 9.3 \text { to } 18.1 \times 4.8 \text { to } \\
6.5 \mu \mathrm{m}, \text { av. }=14.0 \times 5.6 \mu \mathrm{m}, \mathrm{L} / \\
W=2.5\end{array}$ & $\cdots$ & $\cdots$ & This study \\
\hline
\end{tabular}


2012). In this study also, the ITS tree alone in both ML and BI analyses could not differentiate C. pseudoboninense, $C$. philodendricola, $C$. boninense, $C$. oncidii, and $C$. cymbidiicola. Multigene analyses had been indispensable for the species-level identification of the genus Colletotrichum in recent decades (Cai et al. 2009, 2011; Damm et al. 2012, 2019; Hou et al. 2016).

C. pseudoboninense was isolated from P. tatei cv. Congo in China and Dendrobium kingianum (CBS 123921) in Japan. The isolate CBS 123921 (= MAFF 238642) was originally identified as C. boninense based on its conidial characters and ITS sequence (Moriwaki et al. 2003). Later, it (CBS 123921) was recognized as an unnamed taxon by forming a single clade on the phylogenetic tree of multiple loci (Damm et al. 2012). In this study, multilocus analysis of seven genes (Fig. 1) showed that isolate CGMCC 3.19755 from P. tatei cv. Congo and CBS 123921 from $D$. kingianum formed a single clade with high BS/PP values (90/1), and a sister group to $C$. boninense. The single-locus tree showed that this species was clearly differentiated from $C$. boninense in $G A P D H$ and $C A L$ phylogenetic trees. The morphology of conidia (CGMCC 3.19755) was similar to that of CBS 123921 (Table 2). Therefore, these two isolates (CGMCC 3.19755 and CBS 123921) grouped together with C. pseudoboninense, which is distinct from $C$. boninense, but belongs to the same species complex. Although the morphology of this species was similar to those of $C$. boninense (described by Damm et al. 2012), the ascospores on OA were aseptate when mature, different from $C$. boninense. This new species was named C. pseudoboninense sp. nov.

As for C. philodendricola, phylogenetic analyses of multiple loci showed that this species was closely related to five species of the CBSC (i.e., C. boninense, C. cymbidiicola, C. oncidii, C. torulosum, and $C$. pseudoboninense). Referring to the features described by Damm et al. (2012), the growth rate of $C$. philodendricola on OA was slower than that of five other species (Table 2); $C$. philodendricola developed the anamorph only on OA; on the other hand, $C$. boninense (CBS 123756) produced the teleomorph. The setae of $C$. philodendricola were aseptate while those of the other five species were 0 to 5 septate. Another species, $C$. philodendri, was first isolated from Philodendron in Germany (Hennings 1904). C. philodendri on Philodendron was thereafter recorded in the U.S.S.R. (BondarzewaMonteverde et al. 1936), Florida (Alfieri et al. 1984), and Korea (Cho and Shin 2004); most recently, C. philodendri was mentioned as the causal agent of leaf spot on Philodendron in New Jersey (Horst 2013). Kobayashi (1958) thought that $C$. philodendri should be a synonym of $C$. gloeosporioides; however, this hypothesis was based only on cultural and morphological characters because of the lack of molecular techniques. Presently, no strains of C. philodendri reported in the original publication are available; moreover, it was impossible to refer to the manuscript by Hennings (1904) in which the author gives the complete morphological descriptions of $C$. philodendra (MB168038). It is, therefore, not possible to compare C. philodendricola and $C$. philodendri for which there is neither a type strain nor a precise and complete description. So, according to morphological and molecular characters, the species (ex-type strain CGMCC 3.19290) on Philodendron was named as C. philodendricola sp. nov.

Recently, C. orchidearum Allescher was isolated from Cattleya sp., Cymbidium hookerianum, and Oncidium flexuosum in China, and identified using morphological and phylogenetic studies (Yang et al. 2011). Then Damm et al. (2019) stated that both C. aracearum (Hou et al. 2016) and C. hymenocallidicola (Ariyawansa et al. 2015) were synonyms of $C$. orchidearum. $C$. orchidearum has been reported on P. selloum in China (Hou et al. 2016) and Philodendron sp. in Iran (Damm et al. 2019). To our knowledge, this is the first formal report of $C$. orchidearum causing anthracnose on $P$. tatei cv. Congo in China.

The colony growth rate is an important feature to distinguish $\mathrm{Col}$ letotrichum species, and the maximum growth temperature is often applied to characterize species (Damm et al. 2012; Weir et al.
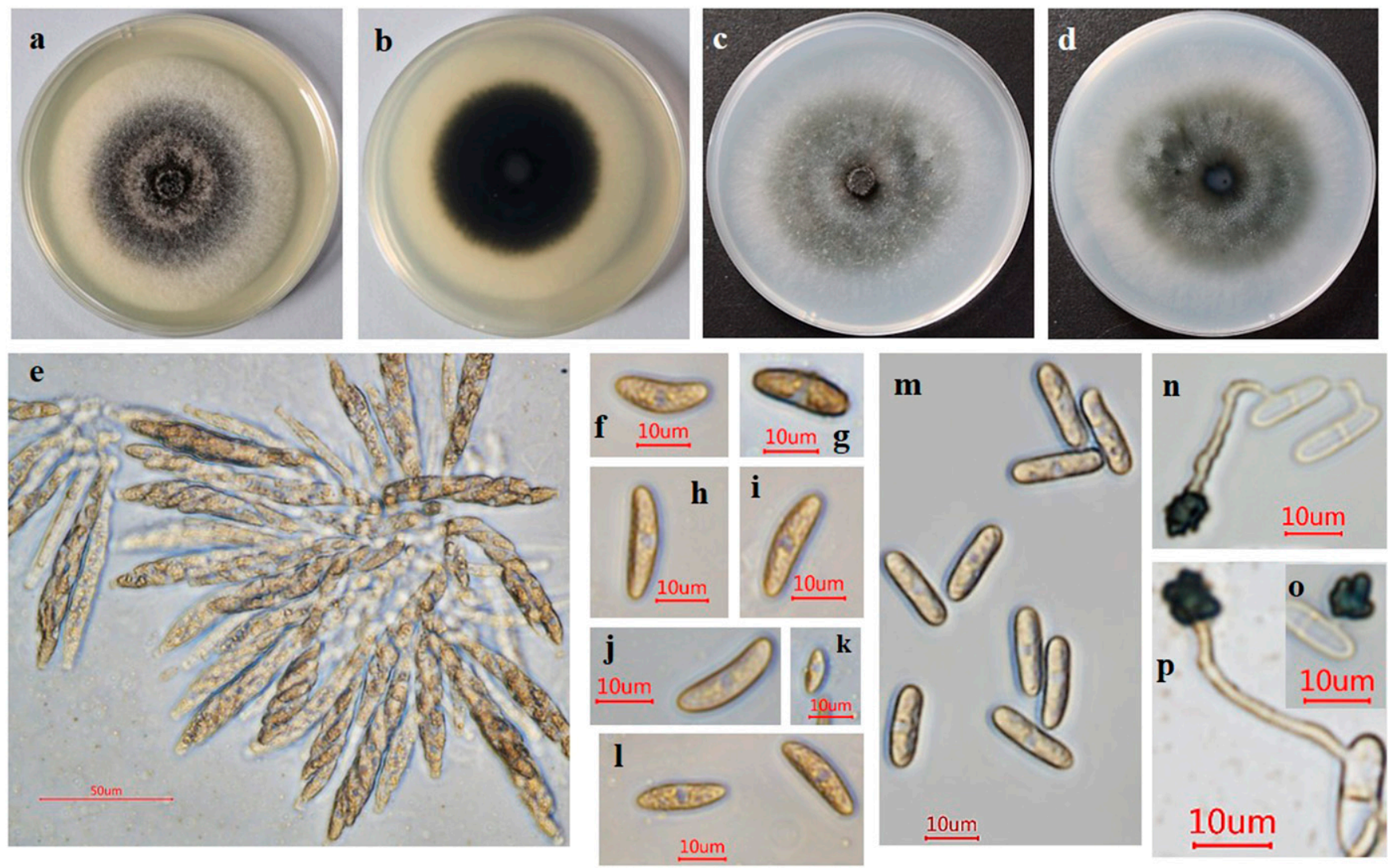

Fig. 5. Morphological features of Colletotrichum orchidearum (strain LZJZ6/CGMCC 3.19756). a, b, m-p, from potato dextrose agar (PDA); c-l, from oatmeal agar (OA). a-b, The colony on PDA at $20^{\circ} \mathrm{C}$ for 8 days in the dark; c-d, the colony on OA at $20^{\circ} \mathrm{C}$ for 8 days in the dark; e, asci; f-I, ascospores; $\mathrm{m}$, conidia; $\mathrm{n}-\mathrm{p}$, appressoria. 
2012). For example, the slower growth rate of $C$. scovillei separated it from C. gloeosporioides, C. siamense, C. fructicola, C. truncatum, C. plurivorum (= C. sichuanensis), and C. brevisporum (Liu et al. 2016). Previous studies have suggested that growth rates were valuable for distinguishing between C. truncatum, C. gloeosporioides, and $C$. acutatum on chilli (Than et al. 2008), C. acutatum and C. gloeosporioides on coffee (Nguyen et al. 2010; Kenny et al. 2012), C. cymbidicola and C. cliviae on orchids (Chowdappa et al. 2014), and C. gloeosporioides and C. karstii on citrus (Daoud et al. 2019). In this study, the growth rate of $C$. philodendricola on OA differentiated it from C. cymbidiicola and C. oncidii described by Damm et al. (2012). Data on growth rates (Table 3) also showed that these three species were distinguishable at 25 or $30^{\circ} \mathrm{C}$ (maximum growth temperature). Considering the importance of temperature for the development of plant diseases, these data would be useful to implement strategies to model and control this disease.

In the present study, the data on pathogenicity indicated that all tested species could infect leaves of $P$. tatei $\mathrm{cv}$. Congo by both spray and point inoculations on both wounded and nonwounded plants. On one hand, the pathogenicity was higher for point inoculation than for spray inoculation as assessed by percent infected leaves $(35.8 \%$ versus $4.7 \%)$. This is the opposite of what was found in a previous study where Fusarium head blight of wheat was more readily caused by spray inoculation (Miedaner et al. 2003). The reasons for the difference in infection efficiency is unknown but may
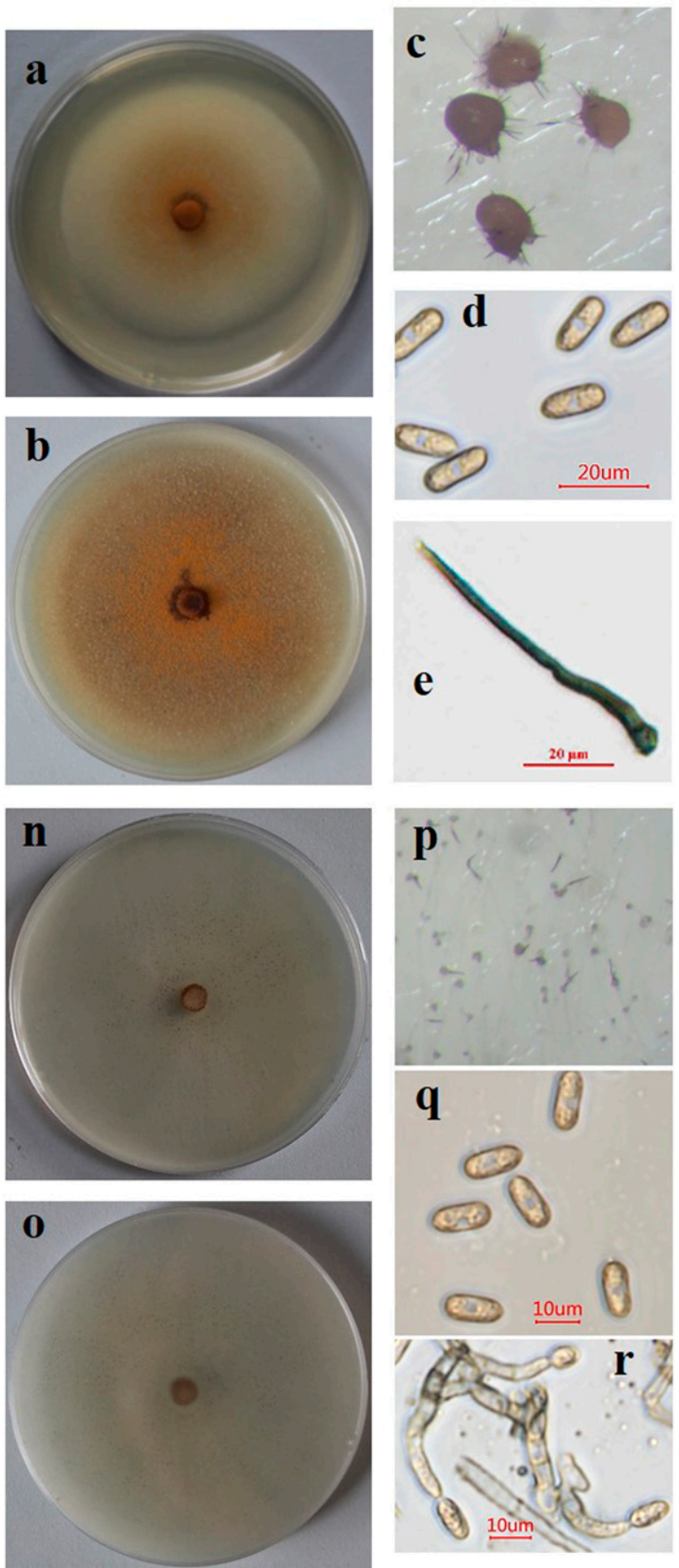
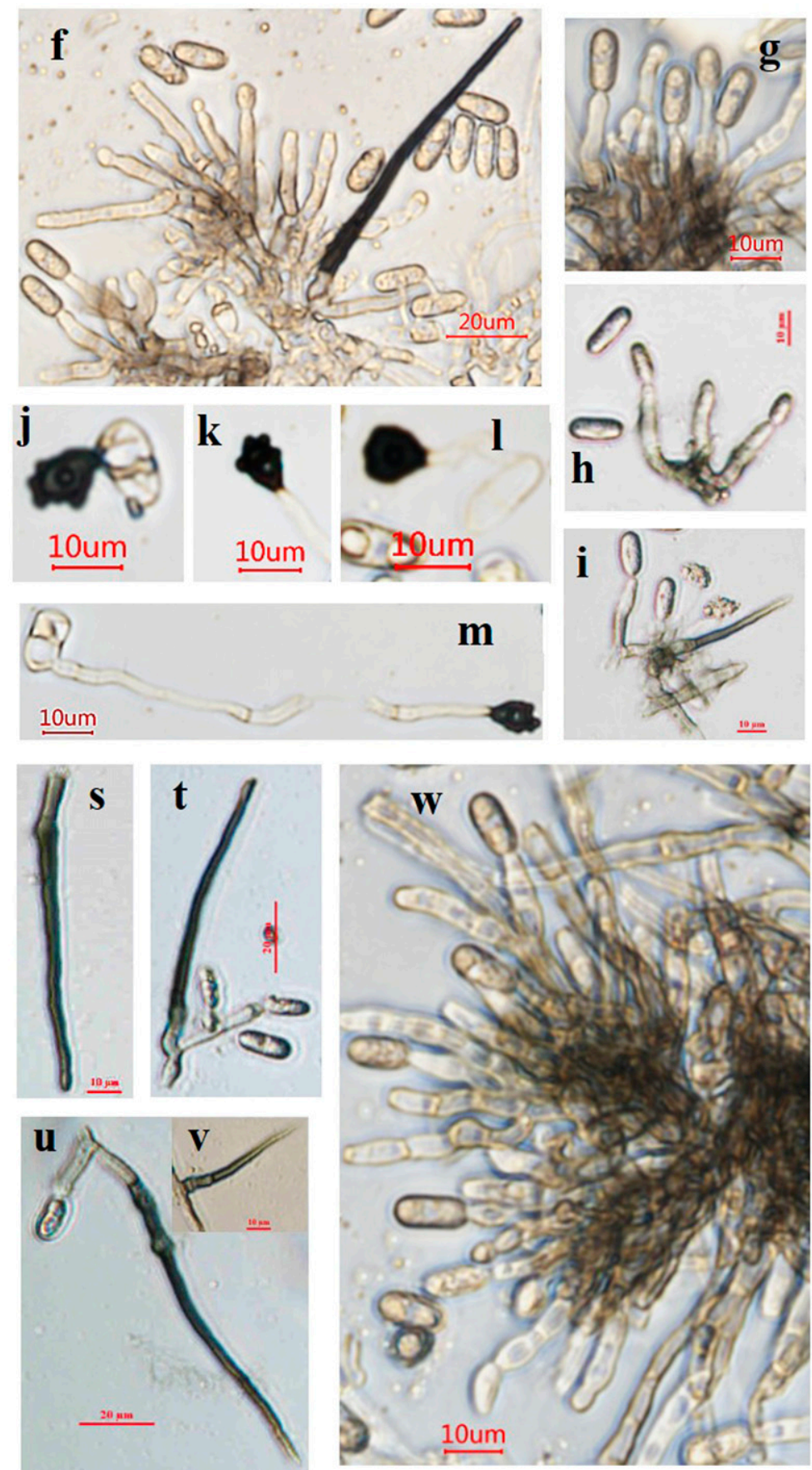

Fig. 6. Morphological features of Colletotrichum philodendricola (ex-holotype strain LZJZ1/CGMCC 3.19290). a-m, From potato dextrose agar. $n-w$, From oatmeal agar a, Culture at $20^{\circ} \mathrm{C}$ for 8 days; $\mathbf{b}, \mathbf{n}, \mathbf{o}$, cultures at $20^{\circ} \mathrm{C}$ for 20 days (o, reverse); c, p, conidiomata and seta; $\mathbf{d}, \mathbf{q}$, conidia; e, f, s-v, seta; $\mathbf{g}-\mathbf{i}, \mathbf{r}, \mathbf{w}$, conidiophores; j-m, appressoria. 
depend on the different fungi (i.e., Colletotrichum versus Fusarium), differences in the type of infected organ (i.e., leaf and spike), and differing environmental conditions. On the other hand, wounding in healthy leaves under point inoculation conditions greatly enhanced (more than 30\%) virulence of Colletotrichum in accordance with previous findings on $C$. capsici $(=C$. truncatum, Pring et al. 1995), although the sizes of lesions between these three species were not significantly different (Table 4). Chen et al. (2017) also confirmed that wounding of the leaves infected with $C$. acutatum and $C$. gloeosporioides could significantly increase the number and sizes of lesions on tea leaves. $C$. cymbidiicola, a sister clade of $C$. philodendricola, could infect the detached leaves of a Cymbidium hybrid by wounding/drop inoculation (Chowdappa et al. 2014); Liu et al. (2018) showed that conidial suspensions of this species were also pathogenetic to nonwounding leaves of Cymbidium ensifolium in China. Damm et al. (2019) showed that $C$. orchidearum, an ex-epitype culture CBS 135131, was isolated from leaf lesions of Dendrobium nobile in the Netherlands but showed a lack of pathogenicity. In other pathogenicity tests, Yang et al. (2011) found that $C$. orchidearum, CORCX6, developed lesions on three fruits by wounding, but no symptom on nonwounding fruits. However, Xu et al. (2016) reported that isolate SAUCC 1407 could infect nonwounding leaves of Arctium lappa.

GCPSR is a pragmatic tool for the assessment of species limits (Quaedvlieg et al. 2014) and has been widely applied to describe species in the fungal kingdom (Geiser et al. 1998; Koufopanou et al. 1997; Laurence et al. 2014; Peterson 2008). In this study, the results of GCPSR analyses correspond to the phylogenetic tree of the seven-loci data (Fig. 1). Therefore, it will be more reasonable for the identification of fungal species (especially for novel species) by adding GCPSR analysis of phylogenetically related species on the basis of morphological and molecular characters.

This is the first study of the diversity of Colletotrichum species associated with anthracnose on $P$. tatei cv. Congo in China. Two novel species (C. pseudoboninense sp. nov. and $C$. philodendricola sp. nov.) were separated phylogenetically from known species of the $C$. boninense complex, and both showed limited morphological differences from the closely related species. C. orchidearum, as a previously described species of COSC, was reported for the first time on P. tatei cv. Congo. All three species showed pathogenicity with minimal variability in virulence as expressed in terms of lesion size. The most prevalent species of anthracnose on $P$. tatei cv. Congo was $C$. philodendricola, followed by C. orchidearum and C. pseudoboninense. This study provides an insight for the identification and pathogenicity evaluation of Colletotrichum species associated with anthracnose on $P$. tate $i \mathrm{cv}$. Congo and is useful for implementation of accurate and appropriate management strategies.
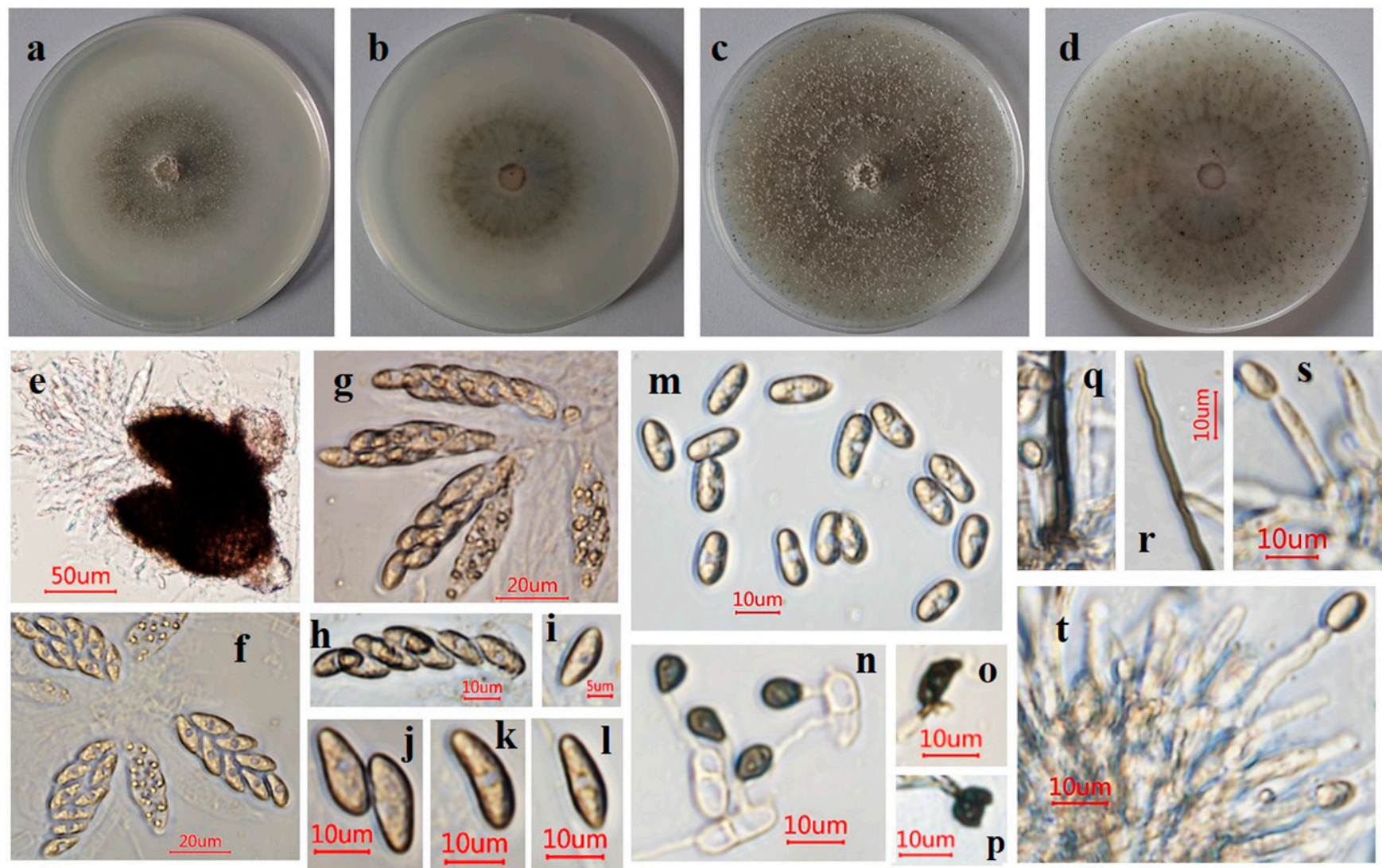

Fig. 7. Morphological features of Colletotrichum pseudoboninense (ex-holotype strain LZJZ5/CGMCC 3.19755). a-l, From oatmeal agar. m-t, From potato dextrose agar. a, b, Culture at $20^{\circ} \mathrm{C}$ for 8 days; $\mathbf{c}, \mathbf{d}$, cultures at $20^{\circ} \mathrm{C}$ for 20 days (d, reverse); e, ascomata; f-h, asci; i-l, ascospores; $\mathbf{m}$, conidia; $\mathbf{n}-\mathbf{p}$, appressoria; $\mathbf{q}, \mathbf{r}$, seta; $\mathbf{s}, \mathbf{t}$, conidiophores.

Table 3. Growth rate ( $\mathrm{mm} / 4$ days) of Colletotrichum isolates in this study cultured on potato dextrose agar (PDA) at different temperatures ${ }^{\mathrm{z}}$

\begin{tabular}{|c|c|c|c|c|c|c|c|c|}
\hline Species (group) & Strains & $5^{\circ} \mathrm{C}$ & $10^{\circ} \mathrm{C}$ & $15^{\circ} \mathrm{C}$ & $20^{\circ} \mathrm{C}$ & $25^{\circ} \mathrm{C}$ & $30^{\circ} \mathrm{C}$ & $35^{\circ} \mathrm{C}$ \\
\hline Colletotrichum 1 & LZJZ1, LZJZ2, LZJZ3, LZJZ4 & $0 \mathrm{a}$ & $0.7 \pm 0.7 \mathrm{~b}$ & $7.2 \pm 0.8 \mathrm{~b}$ & $13.2 \pm 0.9 \mathrm{~b}$ & $15.0 \pm 1.1 \mathrm{c}$ & $6.0 \pm 0.9 \mathrm{c}$ & $1.9 \pm 0.3 b$ \\
\hline Colletotrichum 2 & LZJZ5 & $0 \mathrm{a}$ & $2.1 \pm 0.1 \mathrm{a}$ & $9.0 \pm 0.2 \mathrm{~b}$ & $18.2 \pm 0.5 \mathrm{a}$ & $19.5 \pm 0.2 b$ & $8.6 \pm 0.3 b$ & $0.8 \pm 0.3 \mathrm{c}$ \\
\hline Colletotrichum 3 & LZJZ6 & $0 \mathrm{a}$ & $2.3 \pm 1.5 \mathrm{a}$ & $11.3 \pm 0.4 \mathrm{a}$ & $13.1 \pm 0.4 \mathrm{~b}$ & $21.9 \pm 0.8 \mathrm{a}$ & $30.3 \pm 0.4 \mathrm{a}$ & $11.6 \pm 0.3 \mathrm{a}$ \\
\hline
\end{tabular}

${ }^{\mathrm{z}}$ Columns with the same letter do not differ significantly according with Duncan's test $(P \leq 0.05)$. 
Table 4. Pathogenicity of Colletotrichum isolates on leaves of Philodendron tatei cv. Congo plants, 30 days after wounding and nonwounding inoculation ${ }^{\mathrm{x}}$

\begin{tabular}{|c|c|c|c|c|c|}
\hline \multirow[b]{2}{*}{ Species (group) } & \multirow[b]{2}{*}{ Strains } & \multicolumn{2}{|c|}{ Infected leaves (\%) } & \multicolumn{2}{|c|}{ Lesion diameter (mm) } \\
\hline & & Nonwounded ${ }^{y}$ & Wounded $^{\mathbf{z}}$ & Nonwounded ${ }^{\mathbf{y}}$ & Wounded $^{\mathrm{z}}$ \\
\hline Check & & $\ldots$ & $\ldots$ & $\ldots$ & $\ldots$ \\
\hline Colletotrichum 1 & LZJZ1, LZJZ2, LZJZ3, LZJZ4, & $23.3 \pm 10.4$ & $53.3 \pm 10.4$ & $1.9 \pm 0.7 \times 1.4 \pm 0.4$ & $3.0 \pm 1.9 \times 2.2 \pm 1.2$ \\
\hline Colletotrichum 2 & LZJZ5 & $10.0 \pm 10.0$ & $43.3 \pm 10.4$ & $2.2 \pm 0.6 \times 1.6 \pm 0.4$ & $2.7 \pm 0.9 \times 2.1 \pm 0.7$ \\
\hline Colletotrichum 3 & LZJZ6 & $16.7 \pm 2.9$ & $53.3 \pm 5.8$ & $2.1 \pm 0.8 \times 1.5 \pm 0.6$ & $3.0 \pm 2.1 \times 2.1 \pm 1.1$ \\
\hline
\end{tabular}

$\mathrm{x}$ Table shows incidence of disease by percent and lesion diameter following inoculation of wounded and nonwounded leaves of $P$. tatei cv. Congo. Data represen the mean of three replications, each with 20 leaves on $P$. tatei cv. Congo plants. Check = leaves inoculated with filter papers with sterile water (6 mm diameter), as controls. Ellipsis (...) indicates no symptoms developed on leaves of P. tatei cv. Congo.

y Nonwounded, inoculated with a 6-mm conidial paper.

z Wounded by sterile pinprick, inoculated with a 6-mm conidial paper.

A

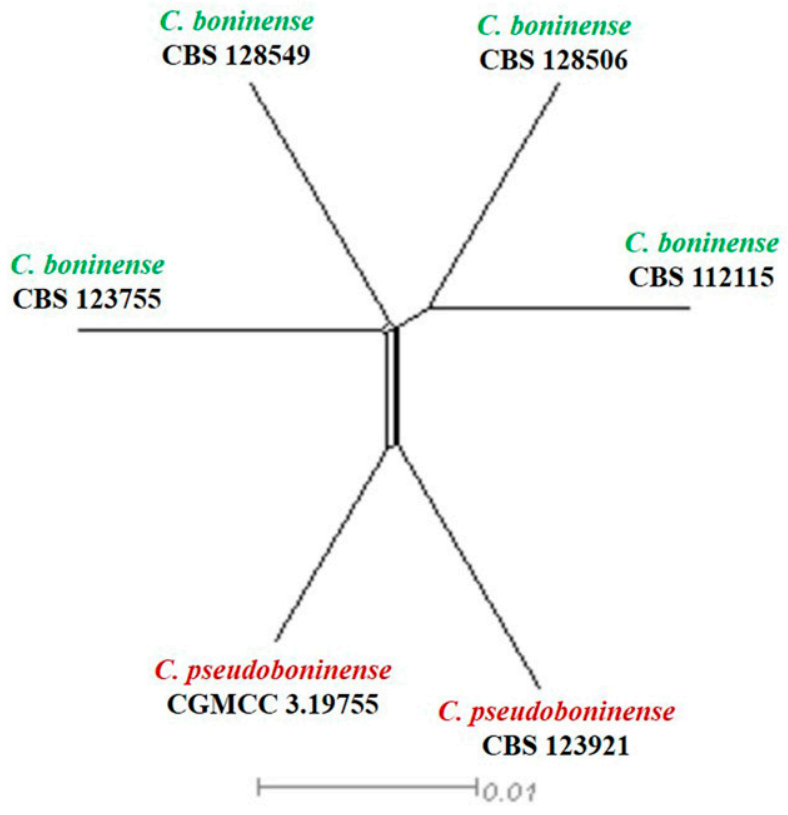

$\Phi_{\mathrm{w}}=1.0$

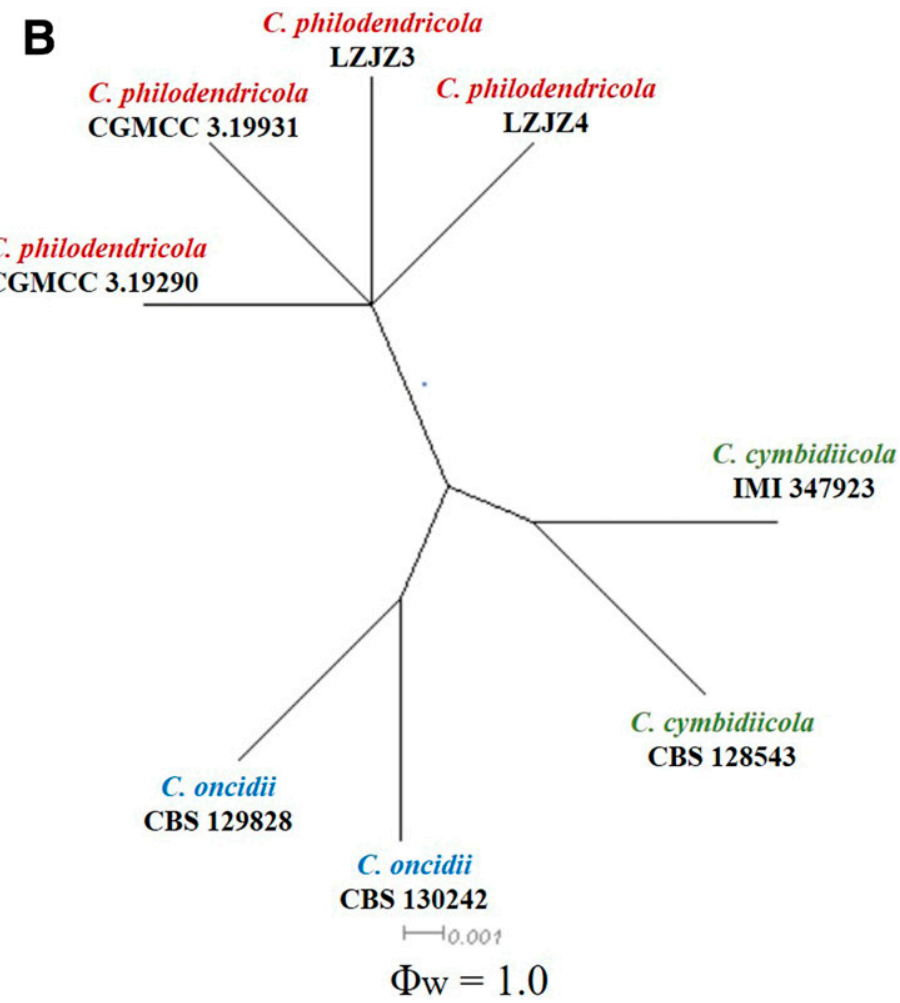

Fig. 8. The results of the pairwise homoplasy index (PHI) test of closely related species using both LogDet transformation and splits decomposition. A, clade A; B, clade B.

\section{Literature Cited}

Alfieri, S. A., Jr., Langdon, K. R., Wehlburg, C., and Kimbrough, J. W. 1984. Index of Plant Diseases in Florida (Revised). Florida Dept. Agric. and Consumer Serv., Div. Plant Ind. Bull. 11:1-389.

Ariyawansa, H. A., Hyde, K. D., Jayasiri, S. C., Buyck, B., Thilini Chethana, K. W., Dai, D.-Q., Dai, Y. C., Daranagama, D. A., Jayawardena, R. S., Lucking, R., et al. 2015. Fungal diversity notes 111-252 - taxonomic and phylogenetic contributions to fungal taxa. Fungal Divers. 75:27-274.

Baroncelli, R., Sarrocco, S., Zapparata, A., Tavarini, S., Angelini, L. G., and Vannacci, G. 2015. Characterization and epidemiology of Colletotrichum acutatum sensu lato (C. chrysanthemi) causing Carthamus tinctorius anthracnose. Plant Pathol. 64:375-384.

Begerow, D., Nilsson, H., Unterseher, M., and Maier, W. 2010. Current state and perspectives of fungal DNA barcoding and rapid identification procedures. Appl. Microbiol. Biotechnol. 87:99-108.

Bondarzewa-Monteverde, V. N., Gutner, L. S., and Nowosselowa, E. D. 1936. Die parasitaren pilze in den Gewachshausern des Botanischen institutes der Akademie der Wissenschaften der USSR. Trudy Bot. Inst. Akad. Nauk S.S.S.R., Ser. 2, Sporov. Rast. 3:715-802.

Bruen, T. C., Philippe, H., and Bryant, D. 2006. A simple and robust statistical test for detecting the presence of recombination. Genetics 172:2665-2681.

Cai, L., Hyde, K. D., Taylor, P. W. J., Weir, B. S., Waller, J. M., Abang, M. M., Zhang, J. Z., Yang, Y. L., Phoulivong, S., Liu, Z. Y., Prihastuti, H., Shivas, R. G., McKenzie, E. H. C., and Johnston, P. R. 2009. A polyphasic approach for studying Colletotrichum. Fungal Divers. 39:183-204.
Cai, L., Udayanga, D., Manamgoda, D. S., Maharachchikumbura, S. S. N. McKenzie, E. H. C., Guo, L. D., Liu, X. Z., Bahkali, A. H., and Hyde, K. D. 2011. The need to carry out re-inventory of plant pathogenic fungi. Trop. Plant Pathol. 36:205-213.

Cannon, P. F., Bridge, P. D., and Monte, E. 2000. Linking the past, present, and future of Colletotrichum systematics. Pages 1-20 in: Colletotrichum: Host Specificity, Pathology, and Host-Pathogen Interaction. D. Prusky, S. Freeman, and M. Dickman, eds. APS Press, St. Paul, MN.

Cannon, P. F., Damm, U., Johnston, P. R., and Weir, B. S. 2012. Colletotrichum current status and future directions. Stud. Mycol. 73:181-213.

Cavalcante, G. R., Barguil, B. M., Vieira, W. A., Lima, W. G., Michereff, S. J., Doyle, V. P., and Câmara, M. P. 2019. Diversity, prevalence, and virulence of Colletotrichum species associated with lima bean in Brazil. Plant Dis. 103: 1961-1966.

Chen, L., Rong, Y., and He, G. 2012. Establishment of tissue culture regeneration system for Philodendron con-go. North. Hortic. 1:120-121.

Chen, Y., Qiao, W., Zeng, L., Shen, D., Liu, Z., Wang, X., and Tong, H. 2017. Characterization, pathogenicity, and phylogenetic analyses of Colletotrichum species associated with brown blight disease on Camellia sinensis in China. Plant Dis. 101:1022-1028.

Cho, W. D., and Shin, H. D. 2004. List of plant diseases in Korea, 4th Ed. Korean Society of Plant Pathology, Seoul, Republic of Korea.

Chowdappa, P., Chethana, C. S., Pant, R. P., and Bridge, P. D. 2014 Multilocus gene phylogeny reveals occurrence of Colletotrichum cymbidiicola and C. cliviae on orchids in North East India. J. Plant Pathol. 96:327-334. 
Damm, U., Cannon, P. F., Woudenberg, J. H. C., Johnston, P. R., Weir, B. S., Tan, Y. P., Shivas, R. G., and Crous, P. W. 2012. The Colletotrichum boninense species complex. Stud. Mycol. 73:1-36.

Damm, U., Sato, T., Alizadeh, A., Groenewald, J. Z., and Crous, P. W. 2019. The Colletotrichum dracaenophilum, C. magnum and C. orchidearum species complexes. Stud. Mycol. 92:1-46.

Damm, U., Woudenberg, J. H. C., Cannon, P. F., and Crous, P. W. 2009. Colletotrichum species with curved conidia from herbaceous hosts. Fungal Divers. 39:45-87.

Daoud, H. B., Baraldi, E., Iotti, M., Leonardi, P., and Boughalleb-m'hamdi, N. 2019. Characterization and pathogenicity of Colletotrichum spp. causing citrus anthracnose in Tunisia. Phytopathol. Mediterr. 58:175-185.

French, A. M. 1989. California Plant Disease Host Index. California Department of Food and Agriculture, Sacramento, CA.

Geiser, D. M., Pitt, J. I., and Taylor, J. W. 1998. Cryptic speciation and recombination in the aflatoxin-producing fungus Aspergillus flavus. Proc. Natl. Acad. Sci. USA 95:388-393.

Guarnaccia, V., Groenewald, J. Z., Polizzi, G., and Crous, P. W. 2017. High species diversity in Colletotrichum associated with citrus diseases in Europe. Persoonia. Mol. Phylogeny Evol. Fungi. 39:32-50.

Guarnaccia, V., Vitale, A., Cirvilleri, G., Aiello, D., Susca, A., Epifani, F., Perrone, G., and Polizzi, G. 2016. Characterisation and pathogenicity of fungal species associated with branch cankers and stem-end rot of avocado in Italy. Eur. J. Plant Pathol. 146:963-976.

Hennings, P. 1904. Fungi amazonici IV. a cl. Ernesto Ule collecti. Hedwigia 44: $57-71$.

Horst, R. K. 2013. Page 106 in: Field manual of diseases on garden and greenhouse flowers. Springer, Dordrecht, The Netherlands.

Hou, L. W., Liu, F., Duan, W. J., and Cai, L. 2016. Colletotrichum aracearum and C. camelliae-japonicae, two holomorphic new species from China and Japan. Mycosphere 7:1111-1123.

Huson, D. H., and Bryant, D. 2006. Application of phylogenetic networks in evolutionary studies. Mol. Biol. Evol. 23:254-267.

Kenny, M. K., Galea, V. J., and Price, T. V. 2012. Germination and growth of Colletotrichum acutatum and Colletotrichum gloeosporioides isolates from coffee in Papua New Guinea and their pathogenicity to coffee berries. Australas. Plant Pathol. 41:519-528.

Kobayashi, T. 1958. Taxonomycal view by JA von ARX about anthracnose fungi. J. Jpn. For. Soc. 40:411-413.

Koufopanou, V., Burt, A., and Taylor, J. W. 1997. Concordance of gene genealogies reveals reproductive isolation in the pathogenic fungus Coccidioides immitis. Proc. Natl. Acad. Sci. USA 94:5478-5482.

Laurence, M. H., Summerell, B. A., Burgess, L. W., and Liew, E. C. 2014. Genealogical concordance phylogenetic species recognition in the Fusarium oxysporum species complex. Fungal Biol. 118:374-384.

Lin, B. R., Shen, H. F., Zhou, J. N., Pu, X. M., Chen, Z. N., and Feng, J. J. 2012. First report of a soft rot of Philodendron congo in China caused by Dickeya dieffenbachiae. Plant Dis. 96:452.

Liu, F., Tang, G., Zheng, X., Li, Y., Sun, X., Qi, X., Zhou, Y., Xu, J., Chen, H., Chang, X., Zhang, S., and Gong, G. 2016. Molecular and phenotypic characterization of Colletotrichum species associated with anthracnose disease in peppers from Sichuan Province, China. Sci. Rep. 6:32761.

Liu, Y. N., Mao, F. R., Zhang, H., Wang, L. B., Zheng, S. J., Wang, J. F., Lou, Q., and Liu, J. L. 2018. Colletotrichum cymbidiicola causes leaf spot of Cymbidium ensifolium in Jilin Province, China. Plant Dis. 102:1462.

Ma, X., Nontachaiyapoom, S., Jayawardena, R. S., Hyde, K. D., Gentekaki, E., Zhou, S., Qian, Y., Wen, T., and Kang, J. 2018. Endophytic Colletotrichum species from Dendrobium spp. in China and Northern Thailand. MycoKeys 43:23-57.

Meneses, P. R., Dorneles, K. R., Bellé, C., Moreira-Nuñez, V. L., GaviriaHernández, V., and de Farias, C. R. J. 2019. Detection of Colletotrichum boninense causing leaf anthracnose on Alcantarea imperialis in Brazil. Plant Dis. 103:2125

Miedaner, T., Moldovan, M., and Ittu, M. 2003. Comparison of spray and point inoculation to assess resistance to Fusarium head blight in a multienvironment wheat trial. Phytopathology 93:1068-1072.
Moriwaki, J., Sato, T., and Tsukiboshi, T. 2003. Morphological and molecular characterization of Colletotrichum boninense sp. nov. from Japan. Mycoscience 44:47-53.

Nguyen, P. T. H., Pettersson, O. V., Olsson, P., and Liljeroth, E. 2010 Identification of Colletotrichum species associated with anthracnose disease of coffee in Vietnam. Eur. J. Plant Pathol. 127:73-87.

Nylander, J. A. A. 2004. MrModeltest v2. Program distributed by the author. Evolutionary Biology Centre, Uppsala University, Uppsala, Sweden.

Osiecki, M. W. 2000. Philodendron plant named 'Congo'. U.S. Patent Application No. 09/250,521.

Peterson, S. W. 2008. Phylogenetic analysis of Aspergillus species using DNA sequences from four loci. Mycologia 100:205-226.

Pring, R. J., Nash, C., Zakaria, M., and Bailey, J. A. 1995. Infection process and host range of Colletotrichum capsici. Physiol. Mol. Plant Pathol. 46: $137-152$

Quaedvlieg, W., Binder, M., Groenewald, J. Z., Summerell, B. A., Carnegie, A. J., Burgess, T. I., and Crous, P. W. 2014. Introducing the consolidated species concept to resolve species in the Teratosphaeriaceae.Persoonia. Mol Phylogeny Evol. Fungi 33:1-40.

Rayner, R. W. 1970. A Mycological Colour Chart. Commonwealth Mycological Institute, Kew, UK.

Ronquist, F., Teslenko, M., Van Der Mark, P., Darling, A., Hohna, S., Larget, B., Liu, L., Suchard, M. A., and Huelsenbeck, J. P. 2012. MrBayes v. 3.2: efficient Bayesian phylogenetic inference and model choice across a large model space. Syst. Biol. 61:539-542.

Scandiani, M. M., Ruberti, D. S., Giorda, L. M., Pioli, R. N., Luque, A. G., Bottai, H., Ivancovich, J. J., Aoki, T., and O'Donnell, K. 2011. Comparison of inoculation methods for characterizing relative aggressiveness of two soybean sudden-death syndrome pathogens, Fusarium virguliforme and $F$. tucumaniae. Trop. Plant Pathol. 36:133-140.

Smith, B. J., and Black, L. L. 1990. Morphological, cultural, and pathogenic variation among Colletotrichum species isolated from strawberry. Plant Dis. 74:69-76.

Tai, F. L. 1979. Sylloge Fungorum Sinicorum. Science Press, Academia Sinica, Peking, China.

Tamura, K., Stecher, G., Peterson, D., Filipski, A., and Kumar, S. 2013. MEGA6: molecular evolutionary genetics analysis version 6.0. Mol. Biol. Evol. 30: 2725-2729

Than, P. P., Jeewon, R., Hyde, K. D., Pongsupasamit, S., Mongkolporn, O., and Taylor, P. W. J. 2008. Characterization and pathogenicity of Colletotrichum species associated with anthracnose on chilli (Capsicum spp.) in Thailand. Plant Pathol. 57:562-572.

Vaidya, G., Lohman, D. J., and Meier, R. 2011. SequenceMatrix: concatenation software for the fast assembly of multi-gene datasets with character set and codon information. Cladistics 27:171-180.

Wang, N. Y., Forcelini, B. B., and Peres, N. A. 2019. Anthracnose fruit and root necrosis of strawberry are caused by a dominant species within the Colletotrichum acutatum species complex in the United States. Phytopathology 109:1293-1301.

Weir, B. S., Johnston, P. R., and Damm, U. 2012. The Colletotrichum gloeosporioides species complex. Stud. Mycol. 73:115-180.

Xu, H. J., Zhou, R. J., Fu, J. F., Zhao, J. F., and Liu, L. 2016. First report of anthracnose on Arctium lappa caused by Colletotrichum orchidearum in China. Plant Dis. 100:1010.

Xue, L., Zhang, L., Yang, X. X., Huang, X., Wu, W., Zhou, X., White, J. F., Yong, L., and Li, C. 2019. Characterization, Phylogenetic Analyses and Pathogenicity of Colletotrichum species on Morus alba in Sichuan Province, China. Plant Dis. 103:2624-2633.

Yang, Y. L., Cai, L., Yu, Z. N., Liu, Z. Y., Hyde, K. D. 2011. Colletotrichum species on Orchidaceae in southwest China. Cryptogam., Mycol. 32: 229-253.

Yang, Y. L., Liu, Z. Y., Cai, L., Hyde, K. D., Yu, Z. N., and McKenzie, E. H. C. 2009. Colletotrichum anthracnose of Amaryllidaceae. Fungal Divers. 39: 123-146.

Zhou, Z., Li, Y. L., Yuan, C. Y., and Duan, P. L. 2014. First report of Alternaria alternata causing a leaf spot on Philodendron 'con-go' in China. Plant Dis. 98: 1588 . 